\title{
International Law in the Courts of Singapore: No Longer a Little Island?
}

\author{
Li-ann Thio ${ }^{1}$
}

\section{INTRODUCTION}

This article examines the role and scope of international law within the courts of Singapore, ${ }^{2}$ a former British colony, and makes comparative references to other common law jurisdictions, where appropriate, to highlight points of convergence and divergence in judicial methodology. It considers in particular the reception, interpretation and treatment of treaty law, customary international law and soft law, and also examines the factors that might preclude the court from considering arguments based on international law. It concludes by offering observations on the interaction and impact of international law within the municipal legal order of Singapore.

\section{CONSTITUTIONAL SILENCE AND WESTMINSTER PARLIAMENTARY SYSTEMS}

Like most Asian common law jurisdictions, the Singapore Constitution, which is a modified variant of the Westminster parliamentary system, is silent on the reception and status of international law within the domestic legal order. This is distinct from the approach adopted in contemporary constitution-making in the Post-Cold War era where, the reception and

1 Ph.D. (Cambridge); LL.M. (Harvard); B.A. (Hons.) (Oxford); Barrister (Gray’s Inn, UK), Provost Chair Professor of Law, National University of Singapore; Senior Advisor, Ministry of Foreign Affairs.

2 See generally Li-ann Thio, Reception and Resistance: Globalisation, International Law and the Singapore Constitution, 4(3) National Taiwan University Law Review 335, 335-86 (2009) [hereinafter Thio, Reception and Resistance]; LI-ANN Thio, A Treatise on Singapore Constitutional Law 82-93 (2012) [hereinafter Thio, A Treatise]. 
ranking of international law within the municipal legal system is explicitly provided for. ${ }^{3}$ The Constitution does not specifically identify which government agency has the power to enter into treaties. Following British practice, this falls to the parliamentary executive or Cabinet government. There is no requirement, as in the US model, that the executive needs Parliament's advice and consent in treaty-making.

Judicial receptivity to international law based arguments turns on a range of factors, ${ }^{4}$ not least judicial knowledge of international law. Unfamiliarity with international law can breed a culture of legal resistance ${ }^{5}$ and disposition to treat international legal norms as an exotic creature to gasp at but give no legal weight to, or alternatively, to adopt a dismissive attitude. In terms of British practice, the approach of the courts has been increasingly open to international law, and the predominant approach to customary international law has been monist in orientation, whereby the law of nations is treated as part of the common law. ${ }^{6}$

A key point to note in relation to Singapore practice is that there has been a significant sea change in relation to the treatment of international law based arguments raised before national courts. In the last decade of the

3 See, e.g., Constitution of the Democratic Republic of Timor-Leste May 22, 2002, $\$ 9$. See generally Antonio Cassese, Modern Constitutions and International Law, in 192 Collected Courses of the Hague Academy of International LaW 331 (1985).

4 Thio, Reception and Resistance, supra note 2, at 339.

5 Rosalyn Higgins, Problems \& Process: International Law and How We Use It 206-07 (1994).

6 Somerest v. Stewart, (1772) 98 Eng. Rep. 499 (K.B). This was also the US approach adopted in The Paquete Habana, 175 U.S. 677 (1900). More recently, after an apparent turn to a dualist approach in R v. Keyn, [1876] 2 Exch. Div. 63 (Eng.) which required an Act of Parliament to transform a permissive international legal norm into domestic English law, a more robust monist approach was adopted in Trendtex Trading Corp. v. Cent. Bank of Nigeria, [1977] Q.B. 529 (Eng.). This recognized an exception to the doctrine of precedent or stare decisis insofar as the courts are allowed to declare a new customary international law norm is part of the common law even if an existing precedent is based on an older customary international norm, without legislative intervention. On British practice, see generally Shaheed Fatima, Using International Law in Domestic Courts (1st ed. 2005). 
$20^{\text {th }}$ century, the approach may be characterized as a curt, even contemptuous dismissal of international law. For example, Article 18 of the Universal Declaration on Human Rights ${ }^{7}$ was invoked, presumably to accentuate the weight of the Article 15 constitutional guarantee of religious freedom in the case of Chan Hiang Leng Colin and others v. Public Prosecutor. ${ }^{8}$ This related to the truncation of the religious freedom of the Jehovah's Witnesses community by laws which deregistered them under the Societies Act $^{9}$ and which banned their religious publications under the Undesirable Publications Act, ${ }^{10}$ on the basis that their pacifist orientation was harmful to national security and compulsory military conscription. While noting that arguments were raised that the ban was "a violation of the freedom of religion as enshrined in the Constitution and also a violation of international declarations of human rights," Chief Justice Yong tersely declared: "All things being said, I think that the issues here are best resolved by a consideration of the provisions of the Constitution, the Societies Act and the UPA alone."11 This unwillingness to consider whether Article 18 of the UDHR was applicable to Singapore law, as customary international law perhaps, reflects the statist bias of the Singapore court in the $1990 \mathrm{~s},{ }^{12}$ which unsurprisingly translates into a dualist mentality towards international law. Speaking extra-judicially, this parochialist approach is evident in Chief Justice Yong's declaration, in response to arguments that international law norms challenged the constitutionality of the death penalty: "I am not

7 Universal Declaration of Human Rights, G.A. Res. 217 (III) A, U.N. Doc. A/ RES/217 (III), at 71 (Dec. 10, 1948).

8 Chan Hiang Leng Colin v. Pub. Prosecutor, [1994] 3 SLR(R) 209 (HC) (Sing.).

9 Societies Act, 2014, c. 311 (Sing.).

10 Undesirable Publications Act, 1998, c. 338 (Sing.).

11 Chan Hiang Leng Colin, 3 SLR, 54.

12 The statist bias is evident in the adjudicative method adopted, where the Chief Justice declared extra-textually, a paramount mandate based on the "sovereignty, integrity and unity of Singapore," which trumped all fundamental liberties, operating as a collectivist trump. Id. 64. Dualism is consistent with legal orders where the primary public value is statist, which valorizes security and sovereignty, and thereby resists the contraction of 'domestic jurisdiction' by international legal regulation. 
concerned with international law. I am a poor humble servant of the law in Singapore. Little Island." 13

Since then, particularly under the judicial bench helmed by Chief Justice Chan Sek Keong from 2006 and by Chief Justice Sundaresh Menon from 2012, there has been a shift in the approach towards judicial review, which has been described thus:

The Bench now regularly engages with foreign case law and international legal arguments, produces expository judgments, references academic opinion and has demonstrated a culture of elaborated reason-giving, as opposed to the statist, cursory judgments of a former age. If these reflect a concern with communitarianism, with local conditions and autochthony, it is clear that the trend is towards a "particularism without parochialism," which is to be welcomed. ${ }^{14}$

Other commentators have noted that the various government branches today have demonstrated "a keen appreciation of what international law requires and allows." 15 Indeed, the courts have drawn on international law as a source of constitutional law in Public Prosecutor v. Taw Cheng Kong, where the issue was whether the legislative power of the Singapore Parliament included the power to enact anti-corruption legislation with extra-territorial reach. ${ }^{16}$ The answer was located in the concept of state sovereignty, insofar as it indicates "plenary authority with respect to internal or external affairs." 17

The Court of Appeal held that on secession from the Federation of Malaysia when Singapore became independent on August 9, 1965, "it acquired the attributes of sovereignty." 18 The "inherent nature" of being a sovereign state meant that the Singapore Parliament would have "plenary power" and could enact laws "to regulate the rights and liabilities between

13 K.S. Rajah, Cj on "Death Penalty" Article, Straits Times (Sing.), Oct. 1, 2003, at 6.

14 Thio, A Treatise, supra note 2, at xiii.

15 Chin Leng Lim \& Mahdev Mohan, Ch.05 Singapore and International Law, SINGAPORELAW.SG, http://www.singaporelaw.sg/sglaw/laws-of-singapore/ overview/chapter-5.

16 Pub. Prosecutor v. Taw Cheng Kong, [1998] 2 SLR(R) 489 (CA), g 30 (Sing.).

17 James R. Crawford, The Creation of States in International Law 90 (2d ed. 2007).

18 Taw Cheng Kong, 2 SLR(R) (CA), 30. 
persons in Singapore, or for that matter, anywhere else."19 Parliament could "empower the local courts to punish any person present in its territories for having done physical acts wherever the acts were done and wherever their consequences took effect. Parliament's power, however, would have no legal effect in other countries, except to the extent that those countries permit it." 20 The understanding is that a statute "generally operates within the territorial limits of the Parliament that enacted it." ${ }^{21}$ This understanding of prescriptive and enforcement jurisdiction is consonant with classic international law, as expounded in the Lotus case. ${ }^{22}$ In that case, the Permanent Court of International Justice also observed that "in all systems of law, the principle of the territorial character of criminal law is fundamental," 23 though underscoring this was not an absolute international legal principle ${ }^{24}$ as there are other heads of jurisdiction. Indeed, the Singapore legislature has enacted laws based on the active nationality principle, whereby Singapore citizens may be liable for offences committed outside Singapore contrary to the United Nations Act ${ }^{25}$ which is to facilitate Singapore's compliance with obligations flowing from Article 41 of the UN Charter.

\section{INTERNATIONAL LAW BEFORE NATIONAL COURTS}

The question of international law within municipal legal orders raises the following issues a court may have to consider: first, the court has to ascertain if the international norm raised does in fact have the juridical status of an international legal norm; second, the court must ascertain if the international legal norm applies to the facts at issue; third, it must

\section{$19 \quad I d$.}

20 Id.

21 Id. g9 30, 66. In Island of Palmas (U.S. v. Neth.), 2 R.I.A.A. 829, 838 (Perm. Ct. Arb. 1928), the arbitrator Max Huber stated: "Sovereignty in the relations between States signifies independence. Independence in regard to a portion of the globe is the right to exercise therein, to the exclusion of any other State, the functions of a State."

22 S.S. Lotus (Fr. v. Turk.), Judgment, 1927 P.C.I.J. (ser. A) No. 10 (Sept. 7).

23 Id. $9944-47$.

$24 \quad I d .950$.

25 United Nations Act, 2002, c. 339, \$ 6 (Sing.). 
determine whether the international law norm applies automatically or requires an additional step of legislative incorporation or judicial recognition. Fourth, even if an international legal norm applies, how does it rank vis-à-vis domestic legal sources? Informing this process is the primary issue of whether the international norm is one based on treaty or customary international law.

\section{a. Treaty Law}

\section{DUALISM AND THE SUPREMACY OF DOMESTIC LAW}

Singapore law follows English practice in adopting a dualist approach towards international treaties and domestic law. Consonant with the doctrine of parliamentary sovereignty, British practice knows no notion of the self-executing treaty and treaty norms must be legislatively incorporated through an Act of Parliament before it may be given direct effect within the domestic legal order.

The Singapore High Court in the Sahand case ${ }^{26}$ confirmed that treaties are not self-executing. This flows from a dualist model which treats international and municipal law as distinct systems of law. The court approved of the statement by the House of Lords in J.H. Rayner (Mincing Lane) Ltd. v. Department of Trade and Industry, [1990] 2 AC 418 at 500:

[A]s a matter of the constitutional law of the United Kingdom, the Royal Prerogative, whilst it embraces the making of treaties, does not extend to altering the law or conferring rights upon individuals or depriving individuals of rights which they enjoy in domestic law without the intervention of Parliament. Treaties, as it is sometimes expressed, are not self-executing. Quite simply, a treaty is not part of English law unless and until it has been incorporated into the law by legislation. So far as individuals are concerned, it is res inter alios acta from which they cannot derive rights and by which they cannot be deprived of rights or subjected to obligations; and it is outside the purview of the court not only because it is made in the conduct of foreign relations, which are a prerogative of the Crown, but also because, as a source of rights and obligations, it is irrelevant. ${ }^{27}$

26 The Sahand, [2011] 2 SLR 1093 (HC) (Sing.).

27 J.H. Rayner (Mincing Lane) Ltd. v. Dep’t of Trade \& Indus., [1990] 2 A.C. 418 (H.L.) 500 (appeal taken from Eng.). 
Quentin Loh J. in the Sahand case observed that the English approach was based on preventing the Crown through its treaty-making powers from altering domestic law "without the authority of Parliament": The Parlement Belge. ${ }^{28}$ In principle, this accords some degree of legislative review over executive policy, though this is formal where the Cabinet controls the parliamentary majority, as it does in the Singapore context. Although the Singapore Constitution departs from the British model in being supreme, ${ }^{29}$ Loh J. considered that the English approach was "equally applicable" to Singapore on the basis of Article 38 of the Constitution which vests legislative power in the Legislature. ${ }^{30} \mathrm{He}$ stated it would be contrary to Article 38 "to hold that treaties concluded by the Executive on behalf of Singapore are directly incorporated into Singapore law, because this would, in effect, confer upon the Executive the power to legislate through its power to make treaties." ${ }^{31}$ Without incorporation by primary or subsidiary legislation, a treaty "does not create independent rights, obligations, powers or duties." 32

For example, the United Nations Convention on Contracts for the International Sale of Goods was given effect to by the Sale of Goods (United Nations Convention) Act (Cap 283), section 4, which provides that the Convention provisions "prevail over any other law in force in Singapore to the extent of any inconsistency." This ranks convention provisions over statute law. The United Nations Act (Cap 339) provides that any regulations under this Act will not be invalid because it is inconsistent "with any written law other than the Constitution," 33 preserving constitutional supremacy.

28 The Parlement Belge, [1879] 4 PD 129 at 154-55 (Eng.).

29 Constitution of the Republic of Singapore Aug. 9, 1965, art. 4: "This Constitution is the supreme law of the Republic of Singapore and any law enacted by the Legislature after the commencement of this Constitution which is inconsistent with this Constitution shall, to the extent of the inconsistency, be void."

30 The Sahand, 2 SLR (HC), 33.

$31 \quad I d$.

$32 I d$.

33 United Nations Act, c. 339, § 2(3). 


\section{JUDICIAL REVIEW: THE MEANING OF TREATIES WITHIN THE DOMESTIC LEGAL ORDER AND THEIR RANK VIS-À-VIS DOMESTIC STATUTES}

While the executive may enter into a treaty that creates binding international obligations for Singapore on the international plane, and while the legislature through legislation gives the treaty domestic legal effect, the courts may nonetheless subject these treaties to judicial review, pursuant to the judicial power to declare a statute null and void for inconsistency with the Constitution. ${ }^{34}$ The courts will determine the proper meaning, scope and applicability of such legislation. The courts have imposed heavy sentences for the breach of statutory offences designed to give effect to treaty obligations, to demonstrate the seriousness of Singapore's commitment to a treaty regime. The High Court in Public Prosecutor v. Kuah Kok Choon held that possessing engendered birds without import permits "went against the spirit" of Singapore's commitment to co-operate with other countries "to preserve their endangered species"35 under the Convention on International Trade in Endangered Species of Wild Fauna and Flora (CITES), which Singapore ratified and gave effect to by the Endangered Species (Import and Export) Act ${ }^{36}$ As such, deterrent sentences were warranted.

\section{i. Terms of Statute Wider than Terms of Convention}

To the extent that an Act of Parliament, which seeks to transform treaty law into Singapore law, is inconsistent with the treaty terms, the statute prevails, provided that its wording is clear. ${ }^{37}$

This is evident from the case of Tan Ah Yeo v. Seow Teck Ming, a case involving a collision on the Singapore River between two inland crafts,

34 "The courts, in upholding the rule of law in Singapore, will no doubt readily invalidate laws that derogate from the Constitution which is the supreme law of our land.” Taw Cheng Kong, 2 SLR(R) (CA), g 89.

Pub. Prosecutor v. Kuah Kok Choon, [2000] 3 SLR(R) 752 (HC), g 30 (Sing.).

36 Endangered Species (Import and Export) Act, 2008, c. 92A (Sing.).

37 This is also the Malaysian approach where, in event of a conflict, the general rule is that the statute should prevail: Pub. Prosecutor v. Wah Ah Jee, [1919] 2 FMSLR 193 (S.C.) (Malay.). This followed the English case of Mortensen v. Peters, 8 F.(J) 93 (Scot.) under which courts are bound to give effect to duly passed legislation and are not to consider whether the law is contrary to international law. 
where all parties concerned were Singaporean. ${ }^{38}$ The Maritime Convention (MC) Act 1911 (c57) (UK) was the relevant Act, and had been extended to Singapore during the time of British colonial rule. This imperial Act had been enacted to give effect to two conventions dealing with collisions between vessels and salvage, adopted at a conference in Brussels in 1910. On becoming independent, Singapore formally accepted these conventions.

The plaintiffs argued that the MC Act should be interpreted in line with the Convention since it had been enacted to give effect to it, and as such, should not apply to the case facts. This is because the collision did not involve two sea-going vessels or a sea-going vessel and vessel of inland navigation, as required under Article 1 of the 1910 Collision Convention. ${ }^{39}$ In addition, Article 12 of the Convention provided that national law rather than the convention applied where all relevant parties belonged to the same State.

However, the terms of the MC Act as enacted were broader than those in the Convention. Section 1(1) referred to "two or more vessels" without stipulating what type of vessels they must be while section 2(2) in dealing with loss of life or personal injuries referred to "any person" or "vessel" without qualification. Chao Hick Tin JC did not see any justification for the court to restrictively qualify "vessel" to require at least one be sea-going or that "any person" should mean one parties must hold different citizenship, given the plain and clear meaning of the words. In other words, although the MC Act was enacted to give effect to the two Conventions, Parliament could widen its scope to cover its own nationals or its own inland watercraft. Chao JC said "I know of no general principle of international law which forbids that;" while he accepted that "it is a principle of legal policy that an Act should be interpreted to conform with international law, there is nothing here in conflict between the MC Act and the Collision

38 Tan Ah Yeo v. Seow Teck Ming, [1989] 1 SLR(R) 134 (HC) (Sing.).

391910 International Convention for the Unification of Certain Rules of Law Related to Collision between Vessels and Protocol Signature art. 1, Sept. 23, 1910, [1930] A.T.S. 14 reads: " $[\mathrm{w}]$ here a collision occurs between sea-going vessels or between seagoing vessels and vessels of inland navigation the compensation due ... shall be settled in accordance with the following provisions in whatever waters the collision takes place." 
Convention." ${ }^{40} \mathrm{He}$ clarified that in the event of a "real conflict" ${ }^{41}$ between international and national law, national law must prevail, citing various English cases. He approved a passage from Maxwell on the Interpretation of Statues (12 $\left.2^{\text {th }} \mathrm{Ed}, 1969\right)$ at page183:

Under the general presumption that the legislature does not intend to exceed its jurisdiction, every statute is interpreted, so far as its language permits, so as not to be inconsistent with the comity of nations or the established rules of international law, and the court will avoid a construction which would give rise to such inconsistency unless compelled to adopt it by plain and unambiguous language. But if the language of the statute is clear, it must be followed notwithstanding the conflict between municipal and international law which results.

He hastened to add that a state could not breach an international legal obligation with impunity and that he regarded state responsibility on the international plane as "a distinct and separate matter." ${ }^{2}$

\section{ii. Scope of the Presumption of Concordance with International Law in Interpreting Domestic Legislation}

Subsequent cases have affirmed the proposition that courts apply the presumption that Parliament intends to conform with international law or indeed, international comity: Public Prosecutor v. Taw Cheng Kong. ${ }^{43}$ In The Sahand, Loh J. underscored that "the courts will always strive to give effect to Singapore's international obligations within the strictures of our Constitution and laws." ${ }^{4}$ In Yong Vui Kong v. Public Prosecutor, the Court of Appeal agreed that "domestic law, including the Singapore Constitution, should, as far as possible, be interpreted consistently with Singapore's

40 Tan Ah Yeo, 1 SLR(R), gg 13-14.

41 Id. 15. The Court of Appeal in Seow Teck Ming v. Tan Ah Yeo, [1991] 2 SLR(R) 38 (CA) (Sing.) agreed at paragraph 18, noting that the scope of the Maritime Conventions Act 1911 was wider than that of the Convention but not in conflict with it.

42 Tan Ah Yeo, 1 SLR(R), 16.

43 Taw Cheng Kong, 2 SLR(R) (CA), at 209.

44 The Sahand, 2 SLR (HC), 33. 
international legal obligations." ${ }^{25}$ Loh J. in The Sahand also briefly observed the "truism" that the executive could consider Singapore's international obligations when exercising its legal discretion, provided "it is not ultra vires the empowering law or the Constitution." 46 Presumably, the adoption of the Tripartite Declaration on Equal Remuneration for Men and Women Performing Work of Equal Value on November 6, 2002, to give effect to ILO Convention 100 on Equal Remuneration, which Singapore ratified in May 2002, was such an exercise of executive discretion by the Manpower Ministry. ${ }^{47}$

However, in Public Prosecutorv. Tan Cheng Yew, the High Court noted there were "defined limits" within which the canon of interpretation that courts would endeavor to interpret domestic statutes in accordance with a state's international treaty obligations operated. ${ }^{48}$ The case itself concerned the rule of specialty and the basis on which Tan could be extradited from Germany to Singapore for criminal breach of trust, whether this was governed by the terms of the narrower Article VII, Singapore-Germany Extradition Treaty ${ }^{49}$ or the wider section 17(a) of the Singapore Extradition Act. ${ }^{50}$ The latter is broader in providing that a person surrendered by a foreign state may only be tried for "the offence to which the requisition of his surrender relates" (first proviso of section 17(a)) or under the broader limb, "any other offence of which he could be convicted upon proof of the facts on which that requisition was based." (second proviso of section 17(b)). Article VII may not be brought to trial "for any other crime or on account of any other matters than those for which the extradition shall have taken place."

45 Yong Vui Kong v. Pub. Prosecutor, [2010] 3 SLR 489 (CA), 59 (Sing.).

46 The Sahand, 2 SLR (HC), 35.

47 Indus. АRв. Ст., http://www.iac.gov.sg/collective-agreements/preparing-a-ca/ sample-clauses (last updated Nov. 20, 2014).

48 Pub. Prosecutor v. Tan Cheng Yew, [2013] 1 SLR 1095 (HC) (Sing.).

49 This has its roots in the United Kingdom-Germany Treaty for the Mutual Surrender of Fugitive Criminals 1872 was entered into in 1960 and extended to Singapore. The provisions for extradition between Singapore and Germany are set out in the Second Schedule of the Federal Republic of Germany (Extradition) Order 1960.

50 Singapore Extradition Act, 2000, c. 103 (Sing.). 
Because it was "trite law that Singapore follow[ed] a dualist position," ${ }^{51}$ the High Court held that Singapore's international law obligations under the Extradition Treaty did not give rise to individual rights and obligations in the domestic context "until and unless transposed into domestic law by legislation." ${ }^{52}$ As such, the issue of whether Article VII or section 17(a) prevailed did not arise, as "they exist on different planes." As such, Article VII could not directly apply to circumscribe the prosecutor's power to charge an extradited person as this was governed by the terms of the Extradition Act that "gives domestic effect to the entirety of Singapore's obligations to other states" ${ }^{53}$ under the various extradition treaties Singapore is party to.

As such, the High Court rejected the view that the scope of section 17(a) be truncated by requiring it to be read consistently with Article VII, as the words in section 17(a) were not "abstruse" 54 and should be given a natural meaning. In relation to the canon of interpretation of reading a domestic statute in accordance with international treaty obligation, Lee Seiu Kin J. approvingly cited Lord Diplock in the English Court of Appeal decision of Salomon v. Commissioners of Customs \& Excise to the effect that the clear and unambiguous terms of legislation "must be given effect to, whether or not they carry out Her Majesty's treaty obligations, for the sovereign power of the Queen in Parliament extends to breaking treaties." 55 As such, any remedy for an international wrong "lies in a forum other than Her Majesty's own courts." ${ }^{26}$ Where the terms of legislation are unclear and "reasonably capable of more than one meaning," and "the treaty itself becomes relevant" as the prima facie presumption arises that Parliament "does not intend to act in breach of international law." 57

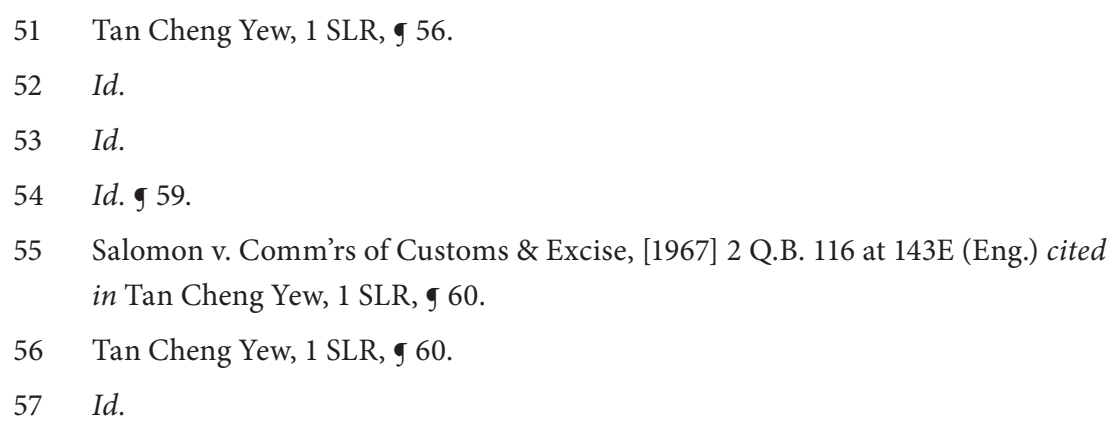


iii. Scope of Prosecution Power in Extradition Cases: Governed by

Treaty or Statutory Regime - Considerations Arising from Monist /

Dualist Jurisdictions

Lee J. in Tan Cheng Yaw noted that the respondent was asking the court not to resolve an ambiguity but to ignore purportedly ambiguous words ("requisition" and "any other offence")..$^{58}$ As extradition was an exercise of sovereign power or dominium of the sending state to surrender a fugitive, rooted in "the Grotian tradition of territorial sovereignty" 59 the Singapore court was not in a position to "go behind the discretion exercised by the Executive of another country." ${ }^{\prime 60}$ It accepted as conclusive a verbal note confirming that the judicial and executive arms of Germany under their internal law base extradition not on the particular charge stated in the requisition but the factual circumstances surrounding the charge. There was nothing in the principle of comity between nations requiring a restrictive construction of section 17 (a), which governed prosecution powers after extradition.

Lee J. noted obiter that comity in this context "must refer to the position that the sending state takes on the specific extradition and subsequent prosecution of an individual." ${ }^{11} \mathrm{He}$ observed that the American specialty rule based on comity of nations and respect for foreign relations set out in treaty arrangements was based on protecting and prioritizing the position of the sending state "against abuse of its discretionary act of extradition." 62 He noted that as America was a monist jurisdiction where ratified treaties were self-executing, US courts considered the interpretation and breach of extradition treaties directly "to determine if any individual rights" ${ }^{\prime 63}$ had been infringed, given that the treaty automatically gave rise to domestic rights and obligations. In contrast, courts in dualist countries approached the issue not from an "individual rights" model but a state centric one which

\footnotetext{
$58 \quad I d .961$.

$59 \quad I d .98$.

$60 \quad$ Id. 90.

$61 \quad I d .965$.

62 Ouseley J., Welsh v. Sec'y of State for the Home Dep't, [2007] 1 W.L.R. 1281 (Divisional Ct.) 37 (Eng.); Tan Cheng Yew, 1 SLR, 65.

63 Tan Cheng Yew 1 SLR, 66.
} 
asked "whether the prosecution is in conformity with domestic law." ${ }^{4}$ That is, the focus is on the scope of statutory obligations owed by a state to an individual with the extradition treaty "only tangentially in issue." ${ }^{\prime 5}$ It was clear that comity might be of immediate relevance in monist jurisdictions in determining whether a breach in an extradition treaty disabled prosecution for an offence; however, Lee J. noted it was "much more equivocal" how comity might apply to the different inquiry of whether prosecution conformed to domestic law. ${ }^{66}$

He noted in passing a novel legal argument which would have "benefitted from fuller argument," which he described as an "individual rights" conception of the specialty rule. ${ }^{67}$ This drew from a statement in the English case of $R v$. Seddon ${ }^{68}$ that located the rationale for the principle of specialty principally in inter-state obligations though "it may owe something to the protection of the individual." ${ }^{\prime 69}$ It was left open whether this was to inform a reading of section 17 (a) or provide an independent ground of challenge. Lee J. offered a "tentative observation" that much of the theoretical debate was motivated by American jurisprudence addressing self-executing treaties and the question of whether extradited persons had standing drawn from an independent or derivative right in domestic courts to raise breaches of treaty specialty provisions. ${ }^{70}$ However, the issue of whether a specialty rule in an extradition treaty was additionally premised on an individual rights protection rationale was academic in Singapore as "any individual rights that can be asserted in domestic courts" had to be derived from implementing legislation in a dualist system. ${ }^{71}$

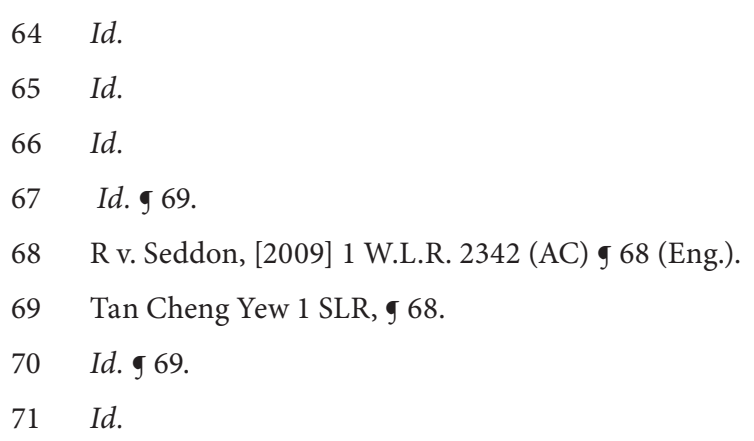




\section{INTERNATIONAL LAW AS PART OF THE INTERPRETIVE MATRIX}

\section{i. Unincorporated Treaties \& Judicial Review: Legitimate Expecta- tions?}

The English practice is to operate on a presumption that Parliament will not legislate contrary to an unincorporated treaty. ${ }^{72}$ This favors a certain interpretation in the event of statutory ambiguity, the one consonant with treaty terms.

The Australian High Court found that the Convention of the Rights of the Child, which Australia had ratified but not incorporated into domestic law still had "significance" in determining the residency permit of a Malaysian who had married and had three children with an Australian citizen in Minister of State for Immigration and Ethnic Affair v. Teoh. ${ }^{73}$ The relevant treaty norm related to the primary consideration of the best interests of the child in all actions concerning children. The High Court stated that international treaty norms which declare "universal fundamental rights" may be used by the courts "as a legitimate guide to developing the common law," though caution was advocated lest such an interpretive approach be viewed as "a backdoor means of importing an unincorporated convention into Australian law." ${ }^{74}$ It declared that the executive government had made a "positive statement" by ratifying the treaty that it intended to live up to its provisions, which provided an "adequate foundation for a legitimate expectation," absent contrary statutory provisions. ${ }^{75}$ This went to finding that procedural fairness required that Teoh be given notice and a hearing before deported. Disgruntled, the Australian government issued executive statements $^{76}$ that same year that sought to terminate the uncertainty the

72 Regina v. Sec'y of State for the Home Dep't, [1991] 1 A.C. 696 (H.L.) (appeal taken from Eng.).

73 Minister of State for Immigration \& Ethnic Affair v. Teoh (1995) 183 CLR 273 (Austl.).

$74 \quad$ Id. 28.

$75 \quad$ Id. 34.

76 Susan Roberts, Minister of State for Immigration and Ethnic Affairs v. Ah Hin Teoh: The High Court Decision and the Government's Reaction to It, 2(1) Australian Journal of Human Rights 10 (1995), available at http://www.austlii.edu.au/au/ journals/AJHR/1995/10.html\#fnB31. 
Teoh decision had imported into government activity, ${ }^{77}$ thus precluding the finding of legitimate expectations based on ratified but unincorporated treaties, ${ }^{78}$ which would have had the effect of expanding the law regarding the effect of treaties.

There has been no Singapore case on the use of international law to ground legitimate expectations; Australian courts are perhaps more ready to refer to international law as a "legitimate and important influence on the development of the common law," particularly where universal human rights are concerned. ${ }^{79}$

\section{ii. Reference to Convention Terms in Interpreting Statutory Terms}

Section $9 \mathrm{~A}(3)$ of the Interpretation $\mathrm{Act}^{80}$ permits reference to any treaty or international agreement referred to in the written law. In addition, Loh J. in The Sahand, noted that international law could fall within the compass of "extrinsic materials" which section 9A(2) of the Act stated was permissible to use in interpreting primary or subsidiary legislation if they assisted in ascertaining the meaning of the provisions. ${ }^{81}$

77 Officials would need to know which treaty would be relevant and what their effect would be, in relation to a possibility that their discretionary powers must be exercised in accordance with a legitimate expectation. Government officials may not be aware of either the contents, or even existence of such treaties. Id.

78 "The Court, although acknowledging that a treaty does not become part of municipal law, regarded the Convention as having legal effect, for why otherwise would government officials be required to act in a particular way, on pain of legal sanctions if they did not do so? If the decision is not to be regarded as self-contradictory, it must have created a new exception to the general rule regarding the effect of treaties that have not been incorporated by statute in the law of Australia." See Sir Harry Gibbs, Chapter Seven: Teoh: Some Reflections, 15 Upholding the Australian Constitution (2003), available at http://www. samuelgriffith.org.au/papers/html/volume15/v15chap7.html.

79 Mabo v. Queensland (No. 2) (1992) 175 CLR 1 (Austl.) (international human rights standards invoked as a challenge against racist conception of terra nullius upon which Crown Title rested).

80 Interpreting Act, 1985, c. 1 (Sing.).

81 The Sahand, 2 SLR (HC), 6. 
In $\mathrm{Ng}$ Kwok Chun v. Public Prosecutor ${ }^{82}$ the court examined the meaning of "import" in the UN Single Convention on Narcotic Drugs (1961) to which Singapore acceded in 1973, to interpret the meaning of "import" within section 7 of the Misuse of Drugs Act (MDA) ${ }^{83}$ which was enacted to give effect to Convention obligations. They rejected the narrow reading of "import" in the mercantilist sense and preferred a wider reading as given by section 2 of the Interpretation Act. ${ }^{84}$ This meant "to bring or cause to be brought into Singapore by land, sea or air." ${ }^{\prime 5}$ The Court noted the legislative intent of the Act was to control dangerous or harmful drugs, such that the Act was directed not simply at the control of the use and distribution of drugs in Singapore, but also the movement of drugs through Singapore for distribution elsewhere. ${ }^{86}$ The Court then referred to the definition of "import" in Article 1(1)(m) of the Convention ("the physical transfer of drugs from one state to another state ...") and found there was nothing in this giving "import" in section 7 of the MDA a narrower meaning than that ascribed to it by the Interpretation Act: "It is clear that Parliament intends to give effect to its international obligations, and 'import' in $\mathrm{s} 7$ of the Act must have the same meaning as that given by the Interpretation Act (Cap 1)." ${ }^{87}$ Further, the Convention indicated that comity required Singapore to exert "every effort to prevent illegal movement of drugs," including where Singapore was used as the transit point for drug movement between countries. A narrow judicial reading of "import" would frustrate the legislative intent and policy to give "import" in the MDA the meaning given to it by the Interpretation Act. ${ }^{88}$

82 Ng Kwok Chun v. Pub. Prosecutor, [1992] 3 SLR(R) 256 (CA) (Sing.).

83 Misuse of Drugs Act, 2008, c. 185, $\$ 7$ (Sing.) ("Except as authorised by this Act or the regulations made thereunder, it shall be an offence for a person to import into or export from Singapore a controlled drug.").

84 Interpreting Act, c. 1.

85 Id.

86 Ng Kwok Chun, 3 SLR(R), gg 12-13.

87 Id. 22.

88 Id. 35. 


\section{iii. Giving Effect to Security Council Resolutions within the Domestic Legal Order through Subsidiary Legislation}

In the Sahand case, the court had to consider the effect of various binding United Nations Security Council Resolution 1737, 1747, 1803, and 1929 ("the Iran Resolutions"). Operative paragraphs 13-15 of Resolution 1737 required all states to implement an assets freeze in relation to assets owned and controlled by designated entities as identified in the Annex, which were associated with supporting Iran's nuclear proliferation activities. States were to ensure that their nationals or any persons or entities within their territories did not make economic resources available for designated entities. Certain exemptions were listed.

Singapore implemented these obligations through subsidiary legislation, namely, the Monetary Authority of Singapore (Sanctions and Freezing of Assets of Persons - Iran) Regulations 2007 (S 104/2007) ("the MAS Regulations") and the United Nations (Sanctions - Iran) Regulations 2007 (S 105/2007) ("the UN Regulations"). The UN regulations are designed to give effect to the Iran resolutions and apply to persons in and citizens of Singapore, excepting financial institutions subject to the directions of the Monetary Authority of Singapore under section 27A of the MAS Act. The Minister or designated person under regulation 14 of the UN regulations may by written notice exempt any person (which would be a body of corporate or unincorporated persons under section 2(1) of the Interpretation Act) or activity from the operation of the regulations, provided this is consistent with the UN Security Council's intent as expressed in its Resolutions. The MAS regulations applies to all financial institutions in Singapore and seeks to give effect to the Iran Resolutions through regulations 5(1) and (2) which require any financial institution in possession or control of economic resources owned or controlled by any designated person to freeze such assets. Exemptions apply as regulation 5(3) provides, such as funds for basic expenses like food and rent or payment of professional or legal services fees, funds subject to any judicial, administrative or arbitral lien or any extraordinary expenses. This is subject to MAS determination which "would be sufficient in the domestic sphere." 89

The issue was whether certain vessels were subject to assets freeze under the terms of the Iran Resolutions. If so, the financial institutions 
covered by MAS regulations would not be able to receive any funds or financial assets from designated entities as consideration for furnishing a guarantee to secure the release of arrested vessels as such funds would have to be frozen once received. This would impact the arrest of vessels owned by designated entities.

On the facts, the defendants did not fall within the designated entities under the relevant Resolution and so there was no question of applying the implementing legislation directly or indirectly on them. ${ }^{90}$

\section{iv. Giving Indirect Effect to an Unenacted Chapter VII UN Charter Se- curity Council Resolution Provision by a Common Law Presumption}

Loh J. in the Sahand case stated obiter that it might be possible to give indirect effect to a Security Council Resolution paragraph which had not been enacted, in being used as an interpretive aid to explain domestic law obligations. In the instant case, operative paragraph 15 of the Security Council Resolution 1737 did not prevent a designated person from making a due payment under a contract entered prior to the listing of such person or entity, provided the relevant States determined the contract did not relate to any prohibited items or financial assistance.

This was not expressly enacted in the MAS Regulations but Loh J. said the court could give "indirect effect" to paragraph 15 by applying a common law principle against retroactivity: "that Parliament is presumed not to have intended to alter the law applicable to past events and transactions in a manner which is unfair to those concerned in them, unless a contrary intention appears," as stated by Staughton L.J. in Secretary of State for Social Security $v$. Tunnicliffe. ${ }^{91}$ The presumption had to be applied consistently with the object of the MAS regulations, to give effect to the

$90 \quad$ Id. 62.

91 Sec'y of State for Soc. Sec. v. Tunnicliffe, [1991] 2 All E.R. 712 at 724 (Eng.), approved by Lord Nicholls of Birkenhead, Wilson v. First County Trust Ltd. (No 2), [2004] 1 A.C. 816 (H.L.) 19 (appeal taken from Eng.); The Sahand, 2 SLR (HC), 46. This presumption was considered applicable to subsidiary legislation, even if Staughton L.J. was referred to Acts of Parliament. Loh J. indicated it would be "helpful" from a judicial perspective for operative paragraphs 14 (payment of interest and earning to frozen accounts) and 15 (payment under existing contracts unrelated to nuclear proliferation activities) to be expressly enacted, given that the facts did not require him to reach a concluded view. The Sahand, 2 SLR (HC), 47. 
Iran resolutions. The presumption could not be applied with full force, as operative paragraph 15 itself only applied to certain payments under existing contracts; therefore, the common law presumption could apply insofar as the stated criteria in operative paragraph 15 had been met. Thus, "indirect effect" could be given to operative paragraph $15 .{ }^{92}$

\section{THE IMPACT OF TREATY ON DOMESTIC LAW: BLUNTING THE IMPACT OF INTERNATIONAL LAW WITH RESPECT TO INDIVIDUAL RIGHTS}

As far as the executive is concerned, there seems to be a presumption that the domestic legal framework suffices to discharge its international obligations when it becomes party to treaties which address individual rights. In relation to the Internationally Protected Persons Bill, enacted to give effect to the Convention on the Prevention and Punishment of Crimes Against Internationally Protected Persons, ${ }^{93}$ a parliamentary question asked why Article 9 of the Convention dealing with the fair treatment of persons charged with such crimes was not included in the Statute. The response was that no specific provision was needed as anyone prosecuted under the Act "would be entitled to the rights of due process guaranteed under the Constitution and our other laws." 94

It is also clear that as far as executive policy is concerned, Singapore when acceding to a rights-oriented treaty such as the Convention on the

92 The Sahand, 2 SLR (HC), 46. Operative paragraph 15 allows payment under a contract provided (a) the contract is not related to any of the prohibited items, materials, equipment, goods, technologies, assistance, training, financial assistance, investment, brokering or services referred to in paragraphs 3, 4 and 6 above; and (b) the payment is not directly or indirectly received by a person or entity designated pursuant to paragraph 12 above. The relevant state would need to inform the Committee of such intention to authorize payment at least ten working days beforehand.

93 Convention on the Prevention and Punishment of Crimes Against Internationally Protected Persons, opened for signature Dec. 14, 1973, 1035 U.N.T.S. 167; 28 U.S.T. 1975 (entered into force Feb. 20, 1977).

94 Singapore Parliamentary Debates, Official Report (6 March 2008) vol 84 at col 2447 "Internationally Protected Persons Bill" (Zainul Abidin Rasheed, Senior Minister of State (Foreign Affairs)). 
Rights of the Child (CRC) ${ }^{95}$ is of the view that it is not accepting rights "going beyond the limits" prescribed by the Constitution or accepting obligations to introduce new rights as Singapore laws provided "adequate protection and fundamental rights ... in the best interests of the child."96 In addition, no dedicated child rights legislation was adopted to give effect to the CRC.

\section{i. Treaties that Singapore is a Party to}

Despite the absence of dedicated legislation to give effect to the CRC, the apex Court of Appeal has made approving references to CRC norms where these reiterate domestic rules. The idea of joint parental responsibility, the court noted, is "deeply rooted in our family law jurisprudence." It is embodied in section 46(1) of the Women's Charter ${ }^{97}$ which "exhorts both parents to make equal co-operative efforts to care and provide for their children," as noted in CX v. CY (minor: custody and access). ${ }^{98}$ The Court noted that Article 18 of the CRC "also endorses the view that both parents have common responsibilities for the upbringing and development of their child."99 The CRC was referenced merely to demonstrate the generality of joint parenting, with a nod to similar approaches in jurisdictions like England and Australia. Article 18 encapsulated "the universal human value that both parents have common responsibilities for the upbringing and development of their child." 100 The invocation of international law here serves to show how domestic law is harmonized with international (and comparative) standards, and is presented as a set of universal values or alternative legal considerations that frame the interpretive matrix. This reiterative approach minimizes the transformative potential of international law on domestic law and policy.

In $A A G$ v. Estate of $A A H$, deceased, the Court of Appeal had to "regretfully" dismiss an appeal made on behalf of two illegitimate daughters

95 Convention on the Rights of the Child, G.A. Res. 44/25, Annex, U.N. Doc. A/44/49, at 167 (Nov. 20, 1989). Singapore acceded to the CRC in 1995.

96 Instrument of Accession, Convention on the Rights of the Child 3 (Oct. 2, 1995).

97 Women's Charter, 2009, c. 353 (Sing.).

98 CX v. CY, [2005] 3 SLR(R) 690 (CA), g 26 (Sing.).

99 Id.

100 UW v. UX, [2007] SGDC 259, 10 (Sing.) (referring to CRC). 
for maintenance from the deceased's estate under the Inheritance (Family Provisions) Act 1938 (U.K.). ${ }^{101}$ This law discriminated against illegitimate children, flowing from the unchanged value that "the family within marriage was considered to be the only acceptable social grouping in which to raise children." ${ }^{102}$ While adopting a dialogical approach in urging Parliament to consider legal reform to enable the illegitimate child of a deceased person to claim maintenance, the Court of Appeal noted that the CRC requires state parties "to use their best efforts to ensure recognition of the principle that both parents have common responsibilities" in raising a child. ${ }^{103}$ However, "nothing in the Convention compels Singapore to equate an illegitimate child with a legitimate child." 104 This shows how treaty norms may feature as a legal consideration in adjudication, or as a persuasive element deployed in a dialogical approach to Court-Parliament relations.

In the absence of incorporating legislation, Singapore courts are likely to follow the dualist approach of Malaysian courts, as reflected in Kok Wah Kuan v. Pengarah Penjara Kajang, Selangor Darul Ehsan, where the High Court said it could not apply Article 40 (fair trial) of the CRC, to which Malaysia was a party, as it remained unincorporated and therefore in the realm of the Executive. ${ }^{105}$ It would be considered a matter of "judicial vandalism or judicial trespass" rather than interpretation, for the High Court to apply a provision from an unincorporated treaty. ${ }^{106}$ The Malaysian courts thus eschewed giving direct effect to a treaty by applying a treaty provision literally as a corrective, as this might set it in conflict vis-à-vis the Executive.

\footnotetext{
101 AAG v. Estate of AAH, deceased [2009] 1 SLR 769 (CA) g 44 (Sing.).

102 Id. 23.

103 Id. 36.

104 Id.

105 Kok Wah Kuan v. Pengarah Penjara Kajang, [2004] 5 MLJ 193 (HC) 93 (Malay.).

106 Id.
} 
Singapore, like Malaysia, acceded to the Convention on the Elimination of All Forms of Discrimination against Women (CEDAW) ${ }^{107}$ in 1995. ${ }^{108}$ It also did not adopt gender equality legislation and the government has insisted that sex discrimination would be covered by the general Article 12 equality constitutional guarantee. In contrast, Malaysia amended Article 8 (2) of its Constitution in 2001 to include "gender" as a prohibited ground of discrimination. ${ }^{109}$

Malaysian jurisprudence in this respect is instructive, particularly since the Part IV Fundamental Liberties chapter of the Singapore Constitution is derived, with modifications, from Part II of the Malaysian Federal Constitution (1957). ${ }^{110}$

Reference was made to CEDAW norms in interpreting and giving content to Article 8(2) of the Federal Constitution of Malaysia by the High Court in Noorfadilla bt Ahmad Saikin v. Chayed bin Basirun. ${ }^{111}$ The case concerned the dismissal by a public authority of an education officer for being pregnant.

Zaleha Yusof J. noted that the word "gender" was incorporated into Article 8(2) to prohibit discrimination on grounds of gender, in fulfilment of Malaysia's international obligations under CEDAW. ${ }^{112}$ Particular reference was made to the Article 1 definition of "discrimination against women"113

107 Convention on the Elimination of All Forms of Discrimination Against Women, G.A. Res. 34/180, U.N. Doc. A/34/46, at 193 (Dec. 18, 1981). [hereinafter CEDAW].

108 States Parties, United Nations Treaties Collection, http://www.un.org/ womenwatch/daw/cedaw/states.htm (follow "Ratification, Accessions and Successions" hyperlink).

109 Federal Constitution of Malaysia (2010 Reprint) Art 8(2).

110 The Privy Council in Ong Ah Chuan v. Pub. Prosecutor, [1980-1981] SLR 48 (PC), gg 561-62 (Sing.) (noting that the eight article in Part IV were "identical with similar provisions in the Constitution of Malaysia").

111 Noorfadilla bt Ahmad Saikin v. Chayed bin Basirun, [2012] 1 MLJ 832 (HC) (Malay.).

112 Id. at 833.

113 Id. (Article 1 of CEDAW defines "discrimination against women" as any distinction, exclusion or restriction made on the basis of sex which has the effect or purpose of impairing or nullifying the recognition, enjoyment or exercise by women, irrespective of their marital status, on a basis of equality of men and 
and the Article 11(1)(b) obligation of states to take appropriate measures to eliminate gender discrimination in the field of employment. ${ }^{114}$ Specifically, Article 11(2)(a) required state parties to take appropriate measures to prohibition dismissal on grounds of pregnancy. ${ }^{115}$

The High Court endorsed the view, drawing from soft law instruments, ${ }^{116}$ that it was obliged to consider Malaysia's obligations under CEDAW in interpreting Article 8(2) in relation to equality and gender discrimination. ${ }^{117}$ It referenced the Australian case of Minister for Immigration and Ethnic Affairs v. Teoh ${ }^{118}$ for the proposition that where legislation was ambiguous, the court should favor the interpretation which accords to a state's treaty obligations, even if not legislatively incorporated. It concluded by holding that discrimination for pregnancy was a form of gender discrimination because of the "biological fact that only woman has the capacity to become pregnant." 119 This case was distinguished from the Beatrice Fernandez $v$. Sistem Penerbangan Malaysia \& Anor ${ }^{120}$ where the Federal Court held that Article 8(2) did not apply to a private contract whereby an air stewardess was fired for becoming pregnant, as it did not have horizontal application.

Article 2(e) of CEDAW is potentially intrusive, providing that as an implementation measures, state should take "all appropriate measures to eliminate discrimination against women by any person, organization or enterprise." 121 This reaches into the private realm; however, a statute would

women, of human rights and fundamental freedoms in the political, economic, social, cultural, civil or any other field.).

114 Id. at 841.

115 Id.

116 Id. at 842-43 (The Bangalore Principles on the Domestic Application of International Human Rights Norms (1988), produced by a high level judicial colloquium and the Putrajaya Declaration and Programme of Action on the Advancement of Women in Member Countries of the Non-Aligned Movement; Beijing Statement and Fourth World Conference on Women in Beijing.).

117 Id. at 842.

118 Teoh, 183 CLR 273.

119 Noorfadilla bt Ahmad Saikin, 1 MLJ 832 (HC), 32.

120 Beatrice Fernandez v. Sistem Penerbangan Malaysia \& Anor, [2005] 2 CLJ 713 (Fed. Ct.) (Malay.).

121 CEDAW, supra note 107. 
be necessary to prohibit gender discrimination between private actors. CEDAW only applied in public law cases, where legislation or executive action contravened individual rights. Indeed, the Court of Appeal in AirAsia Berhad v. Rafizah Shima Binti Mohamad Aris, ${ }^{122}$ rejected the approach in Noorfadilla, pointing out that CEDAW did not have the force of law in Malaysia because it had not been enacted by local legislation. ${ }^{123}$ Unless treaties were domesticated, they could not be enforced. From a dualist perspective, the Court said this approach was necessary to serve as a "democratic check", to mitigate the lack of "direct participation of parliament in treaty-making." 124 Treaties had to be incorporated as legislators "may regard it necessary to tailor the treaty, through an act of transformation, to match domestic circumstances. ${ }^{125}$ In addition, legislators may want to delay the implementation of parts of the treaty or limit direct application of certain provisions. ${ }^{126}$

Nonetheless, the position in Malaysia is confused, given a later High Court judgment which followed the Noorfadilla approach, such that provisions in the Convention on the Rights of the Child, which Malaysia acceded to in 1995 were treated as incorporated into Malaysian common law. ${ }^{127}$ Articles 3 and 7 of the CRC were raised as the basis for the exercise of inherent judicial power to order the defendant to undergo DNA testing to determine the child's paternity, as this was in the best interest of the child. Further, a minor's right to know and be cared for by his or her parents following Article 7 was not inconsistent with Malaysian law, and was based on the article 8 constitutional guarantee of equal protection of the law, which extended to knowing who his biological father was. The Court

122 AirAsia Berhad v. Rafizah Shima Binti Mohamad Aris, [2014] MLJU 606 (CA) (Malay.).

123 The High Court in SIS Forum v. Dato' Seri Syed Hamid bin Syed Jaafar Albar (Menteri Dalam Negeri), [2010] 2 MLJ 378 (HC), 37 (Malay.) (noting that the Australian case of Teoh had received its "fair share of criticism," and that the approach of Malaysian courts was not to directly accept norms of international law unless incorporated as part of municipal law).

124 AirAsia Berhad, MLJU 606 (CA), 52.

$125 I d$.

$126 I d$.

127 Lee Lai Ching v. Lim Hooi Teik, [2013] 4 MLJ 272 (HC), g 30 (Malay.). 
appeared to discard the precedent of Binsted v. Juvencia Autor Partosa ${ }^{128}$ where forcing one to undergo a DNA test constituted causing voluntary hurt under the section 323 of the Penal Code; it also noted there were no specific statutory restrictions that allowed or disallowed DNA testing to prove paternity. ${ }^{129}$ The CRC as an unincorporated international treaty was thus resorted to, to interpret the content of equal protection and to depart from past precedent.

It is likely that Singapore courts will adopt the same domestic posture as Malaysian courts, given the dualist model for treaties and respect for the separation of powers. Singapore courts would certainly not adopt the activist approach of the Indian court in the noted case of Vishaka $v$. State of Rajasthan ${ }^{130}$ where CEDAW norms and even non-binding recommendations of the CEDAW Committee which has "no enforcement authority,"131 were invoked to enlarge constitutional rights in reading the Article 21 right to life guarantee and the Article 19(1)(g) right to carry on trade safely, as well as the Articles 14-15 equality clauses.

The case itself concerned a brutal gang rape of a social worker. ${ }^{132}$ In what might fairly be characterized as an act of judicial legislation, the Court in the absence of sexual harassment legislation referred to international law norms to read Articles 14, 15, 19, and 21 of the Indian Constitution, to give content and to elaborate "implicit" sexual harassment safeguards supposedly located within these norms. ${ }^{133}$ It referred to Article 11 and 24 of CEDAW and to the general recommendation on Article 11, concluding that gender equality included "protection from sexual harassment and right to work with dignity" which it considered "a universally recognized basic human right." 134

It issued a series of judicially crafted guidelines to prevent sexual harassment at the work places pursuant to Article 32 of the Constitution which requires effective redress of rights violations, to "fill the legislative

128 Binsted v. Juvencia Autor Partosa, [2000] 2 MLJ 569 (HC) (Malay.).

129 Lee Lai Ching, 4 MLJ 272 (HC), 42.

130 Vishaka v. State of Rajasthan, A.I.R. 1997 S.C. 3011 (India).

131 AirAsia Berhad, MLJU 606, 34.

132 Vishaka, A.I.R. 1997 S.C. 3011, g 2.

133 Id. 7.

134 Id. 
vacuum."135 These detailed guidelines which read like a framework law, were to be treated as the law, and to be applied to the public realm and private workplace "until a legislation is enacted for a purpose." 136 Citing cases like Minister of State for Immigration and Ethnic Affair $v$. Teoh, the expansive approach adopted by the Indian courts in the face of legislative failings was that international treaties and norms were to be read to elaborate the meaning and content of fundamental rights "in the absence of enacted domestic law occupying the fields when there is no inconsistency between them." 137

In the face of legislative incompetence, Indian courts may step in to enact quasi-legislation, drawing on international norms to formulate the terms of such guidelines, which in this case declared "These directions would be binding and enforceable in law until suitable legislation is enacted to occupy the field." 138

This is an extraordinary use of international treaties by a domestic court to fashion domestic law.

\section{ii. Treaties that Singapore is not Party to}

When it comes to human rights treaties, Singapore courts do not give weight to treaties which Singapore is not a party to. In contrast, Philippines courts have considered treaties the state is not a party to, such as the International Convention for the Protection of All Persons from Enforced Disappearances, to support actions for Amparo writs, regarding the treaty as if it embodied customary international law. ${ }^{139}$

Singapore courts have consistently rejected right cases from foreign common law jurisdictions influenced by the Inter-American Convention on Human Rights and the European Convention on Human Rights (ECHR), ${ }^{140}$ which generally accord more weight to fundamental rights. ${ }^{141}$

\footnotetext{
135 Id.

136 Id. 16.

137 Id.

138 Id.

139 Razon v. Tagitis, G.R. No. 182498 (S.C., Dec. 3, 2009) (Phil.).

140 European Convention on Human Rights, Nov. 4, 1950, 213 U.N.T.S. 221.

141 Chee Siok Chin v. Minister for Home Affairs, [2006] 1 SLR 582 (HC) (Sing.).
} 
Chee Siok Chin v. Minister for Home Affairs concerned the scope of the freedom of speech and assembly as guaranteed in Article 14 of the Constitution against public order considerations. ${ }^{142}$ The High Court rejected the more rights-protective proportionality standard of review of late adopted by English law, galvanized by the Human Rights Act (1998), which sought to give effect to the ECHR. ${ }^{143}$ This is contrasted with the enthusiastic embrace of the test of proportionality by Hong Kong courts, which regularly draw inspiration from the European Court of Human Rights and Covenant on Civil and Political Rights standards. ${ }^{144}$ The Hong Kong courts' inspiration is incorporated in accordance with Article 39 of the Hong Kong Bill of Rights Ordinance Cap 383 (the UK extended its application to Hong Kong while it was still under British rule. $)^{145}$ Rajah J. underscored the distinctiveness of the Singapore context and constitutional text and the more restrictive formulation of the scope of free speech in Singapore. ${ }^{146}$ He noted that "the infiltration of European law into English law" had left more recent English public order decisions with "neither persuasive nor logical force," as these applied "legal and political conditions that do not and cannot extend to Singapore." 147 Underscoring the need for an autochthonous approach, Rajah J. stressed that the proportionality standard of review was a feature of European jurisprudence rather than the common law and had never been part of Singapore law. ${ }^{148}$ He further noted there were no immutable "universal standards" given the disparate approaches towards acceptable public conduct, as the "margins of appreciation for public conduct vary from country to country as do their respective cultural, historical and

\section{Id.}

143 Id. 5.

144 See, e.g., Leung Kwok Hung v. HKSAR, [2005] 8 H.K.C.F.A.R. 229 (C.F.A.) (where the ECHR and its cases as well as Covenant on Civil and Political Rights norms were cited.).

145 Id.

146 Free speech in Singapore is subject to restrictions on eight stipulated grounds which Parliament deems "necessary and expedient." In contrast, article 10 of the ECHR requires that any restrictions be "necessary in a democratic society," subject to a test of proportionality review. Chee Siok Chin, 1 SLR 582.

147 Chee Siok Chin, 1 SLR, 5.

$148 \quad$ Id. g 87. 
political evolutions as well as circumstances." 149 This is because value judgments are involved, and in the adjudicatory process, the court would be guided "by the manifest intent and purport of both the Constitution and domestic legislation." 150

In the field of human rights law, arguments based on international or regional norms are not a force for harmonization; instead, they are discussed to demonstrate difference and divergence of views, which is unsurprising, in a plural and postmodern world. Again, this shows the primacy of local particularities, including the supremacy of the constitutional text and of history, in the reading of rights. ${ }^{151}$

\section{CONCLUSION ON TREATIES BEFORE SINGAPORE COURTS}

What is striking about the approach of Singapore courts to treaty law is its state-centricity, both in terms of its dualist posture and the clear ranking of the supremacy of domestic law over treaties and international agreements. ${ }^{152}$ Nonetheless, while breaches of treaty norms may not incur domestic liability, it does not preclude international responsibility. Apart from legislative incorporation, treaty law will have minimal effect on the domestic legal system.

149 Id. 132.

150 Id.

151 Although the ECHR applied to certain British colonies, including Singapore and the Federation of Malaya in 1953, it ceased to apply when these became independent. While former colonies in the Caribbean like Belize modeled their Constitutions after the ECHR, Singapore and Malaysia did not. Yong Vui Kong, 3 SLR (CA), 961.

152 In Pub. Prosecutor v. Salwant Singh s/o Amer Singh, [2003] SGDC 146 (Sing.), an international agreement which sought to stipulate the maximum terms of imprisonment a foreign national which Singapore wanted to extradite and try was found to violate article 93 of the Constitution, which vests judicial power in independent courts. The executive agreement was found to contravene judicial sentencing powers. 


\section{b. Customary International Law}

A distinctive approach is adopted towards customary international law (CIL), an unwritten source of international law, as compared to treaty norms that need to be statutorily incorporated to have domestic legal effect. As the constitution is silent on the reception and status of CIL within the municipal order, ${ }^{153}$ it falls to the courts to determine whether a general international law norm exists and what its content is.

The formation of CIL norms is governed by the finding of two components: general, consistent state practice of sufficient duration, and opinio juris, which is the subject state belief that a norm is to be obeyed because it is legally binding.

\section{Evidence of a Customary International Law Norm}

A clearly established CIL norm may become part of Singapore law and it falls to the judiciary to ensure its juridical status as a binding legal obligation, as opposed to something de lege ferenda.

This is demonstrated in Nguyen Tuong Van v. Public Prosecutor ${ }^{154}$ with respect to the judicial attitude towards Article 36(1) of the Vienna Convention on Consular Relations (VCCR) (1963), ${ }^{155}$ a treaty Singapore was not then a signatory to. This provision relates to the right of consular officers to visit a national of the sending State who is imprisoned or detained, and to arrange for their legal representation. Defense counsel argued that the VCCR applied to Singapore because it is CIL. ${ }^{156}$ In response the Prosecution stated Article 36 was not breached on the facts and was silent as to whether Article 36(1) was CIL.

The High Court found that Article 36(1) was CIL, noting that there was an "established practice" for a state detaining a foreign Australian national,

153 In contrast, CIL is deemed "incorporated" into the Philippines legal system through the constitutional incorporation clause: Cont. (1987), art. II, sec. 2 (Phil.); Pharmaceutical \& Health Care Ass'n v. Health Sec'y Francisco T. Duque III, G.R. No. 173034 (S.C. Oct. 9, 2007) (Phil.).

154 Pub. Prosecutor v. Nguyen Tuong Van, [2004] 2 SLR 328 (HC) (Sing.).

155 Vienna Convention on Consular Relations, opened for signature Apr. 24, 1963, 596 U.N.T.S. 261, 21 U.S.T. 77 (entered into force Mar. 19, 1967).

156 Nguyen Tuong Van (2004), 2 SLR (HC), 55. 
to notify the consular officers of the accused person's state. ${ }^{157}$ This was part of the "standard operating procedure" of the Central Narcotics Bureau; the court drew what it considered a reasonable inference that other Singapore law enforcement agencies would have similar directives. ${ }^{158}$ Kan Ting Chiu J. stated that the directive "suggests the acceptance of the obligations set out in Art 36(1)" which "applies in Singapore." ${ }^{159}$ He noted that the Prosecution "which is in a good position to have knowledge of Singapore's position on this issue, did not assert the contrary" and that "Singapore holds herself out as a responsible member of the international community and conforms with the prevailing norms of the conduct between states." ${ }^{160}$ A form of tacit consent or opinio juris may be derived from the Prosecutor's non-protest against the invocation of Article 36(1) as an applicable standard. The reference to prevailing inter-state norms of conduct suggests both generality and consistency of practice.

Further state practice was referenced to ascertain the content of what "without delay" might mean. ${ }^{161}$ The High Court concluded that Article 36(1) was not breached on the facts; while it required consular notification, it did not stipulate a time period though this was to take place "without delay." 162 In the immediate case, the time period between arrest and notification was about 20 hours. ${ }^{163}$ The High Court noted that Australia, for example, considered three days (72 hours) an adequate period for notification, as

\footnotetext{
157 Id. 24.

158 Id. 35.

159 Id. 36.

160 Id. 99 30-39.

$161 \quad I d .939$.
}

162 Vienna Convention on Consular Relations, supra note 155, art. 36(1)(b) ("if he so requests, the competent authorities of the receiving State shall, without delay, inform the consular post of the sending State if, within its consular district, a national of that State is arrested or committed to prison or to custody pending trial or is detained in any other manner. Any communication addressed to the consular post by the person arrested, in prison, custody or detention shall also be forwarded by the said authorities without delay. The said authorities shall inform the person concerned without delay of his rights under this sub-paragraph.").

163 Nguyen Tuong Van (2004), 2 SLR (HC), 38. 
provided for in its 2000 Agreement on Consular Relations between Australia and the People's Republic of China. ${ }^{164}$

\section{Judicial Recognition as Precursor to Domestic Law Applicability}

To become part of Singapore law, CIL norms do not have to be legislatively incorporated although these do not automatically apply without some receptive act. An established CIL norm only becomes part of Singapore law if there is judicial recognition of it first, absent which the CIL norm in question "would merely be floating in the air." 165 The Court of Appeal in Yong Vui Kong v. Public Prosecutor endorsed the common law approach of Lord Atkin in Chung Chi Cheung v. $R^{166}$ under which international law has no validity "save in so far as its principles are accepted and adopted by our own domestic law." 167 The judicial role in any given case is first to ascertain the relevant rule of international law "which nations accept amongst themselves" and to treat it as incorporated into domestic law "so far as it is not inconsistent with rules enacted by statutes or finally declared by their tribunals." 168 Various jurists, including Brownlie, Oppenheim, and Akehurst were cited in support of this proposition. ${ }^{169}$

Thus, a Singapore court would need to determine that the relevant CIL rule is consistent with Singapore statute law or finally declared by Singapore courts, and "either declare that rule to be part of Singapore law or apply it as part of our law." 170 This declaration and application is needed to operationalize a CIL norm that is "not self-executing." ${ }^{171}$ As I have elsewhere observed, this "suggests a dualist orientation towards CIL

\footnotetext{
$164 \quad I d .939$.

165 Yong Vui Kong, 3 SLR (CA), g 90.

166 Chung Chi Cheung v. R, [1939] A.C. 160 (P.C.), 167-68 (appeal taken from H.K.), cited in Nguyen Tuong Van (2004), 2 SLR (HC), 94.

167 Nguyen Tuong Van (2004), 2 SLR (HC), gg 89-91.

168 Id.

169 Yong Vui Kong, 3 SLR (CA), g 89.

$170 \quad I d$.

171 Id. 91.
} 
law and domestic law, with a monist sensibility in so far as the courts can directly apply CIL without legislative intervention." ${ }^{172}$

This is consonant with the positivist theory that international legal obligation rests on state consent, whether express or tacit, and binds a sovereign state on the basis of auto-limitation.

\section{Ranking CIL Norms}

Arguments have been raised to the effect that CIL norms, where these inform constitutional interpretation, should be received and ranked as part of constitutional law i.e. at the apex of the domestic legal hierarchy.

If this was accepted, statutory or common law norms inconsistent with the Constitution would be void. This would be judicially enforceable and would open the door to international law playing a greater transformative role in the shaping of domestic law.

This argument was raised in Yong Vui Kong v. Public Prosecutor in relation to the meaning of "law" in Article 9 of the Singapore Constitution which provides that no one shall be deprived of life or personal liberty "save in accordance with the law." 173 This hinged on "law" in Article 9 encompassing CIL, that is, Article 9 should be read such that the legislative acts of depriving a person of life or personal liberty must be accomplished in a manner inconsonant with customary international law. International standards would then be directly imported into constitutional construction, as part of the constitutional clause itself.

However, this was rejected by the Court of Appeal in Yong who asserted that once courts had incorporated CIL rules, "it becomes part of the common law," as opposed to having constitutional status, and is thereby "subordinate to statute law." 174 To cloak a CIL norm with constitutional status would reverse the hierarchy of legal rules, which would "nullify any statute or any binding judicial precedent which is inconsistent with it." 175

172 Thio, A Treatise, supra note 2, at 602. This apparently is the Malaysian approach as well. See Chung Chi Cheung v. R, A.C. 160 (Malay.).

173 Yong Vui Kong, 3 SLR (CA), g 11.

$174 I d$.

175 Id. 90. 
Clearly, in the event of a conflict between a CIL rule and domestic statute, the latter prevails. ${ }^{176}$

\section{Determining the Content of a Putative CIL Norm}

The judicial approach in determining the content of a CIL norm is discussed in the section below (Part c).

\section{c. International Human Rights Law, the UDHR and Singapore Courts}

At its inception, the Universal Declaration on Human Rights (UDHR), adopted as a General Assembly Resolution, was a legally non-binding statement of moral aspirations. Today, many, perhaps all of its provisions, have become CIL. ${ }^{177}$ There is no harmony in the attitudes of various Asian courts towards the UDHR; indeed, there are divergent views within single jurisdictions. ${ }^{178}$

176 Nguyen Tuong Van v. Pub. Prosecutor, [2005] 1 SLR 103 (CA), 94 (Sing.); For a comment, see C.L. Lim, The Constitution and the Reception of Customary International Law: Nguyen Tuong Van v. Public Prosecutor, Singapore Journal of Legal Studies 218, 218-33 (2005); See also Star Cruise Services Ltd. $v$. Overseas Union Bank Ltd., [1999] 2 SLR(R) 183 (HC) (Sing.) where the right of innocent passage was found to be a CIL norm but would, if relevant, be subject to the Common Gaming Houses Act. Other CIL norms Singapore courts have recognize include the width of territorial waters and immunity for non- enemy ambassadors: The Trade Resolve, [1999] 2 SLR(R) 107 (HC), 25 (Sing.) and Re Contraband Mails: ex MfcV Conte, [1949] MLJ 5 (Malay.), respectively.

177 Hurst Hannum, The Status of the Universal Declaration of Human Rights in National and International Law, 25 Georgia Journal of INTERNATIONAL and Comparative Law 287 (1995); Kevin YL Tan, Fifty Years of the Universal Declaration of Human Rights: A Singapore Reflection, 20 Singa Pore Law Review 239, 271 (1998).

178 In Mohd EzamMohd Noor v. Ketua Polis Negara, [2002] 4 MLJ 449 (Fed. Ct.), 514 (Malay.), Siti Norma FCJ said the UDHR was not a convention and its principles were declaratory in nature, having no legal force and so not a part of municipal law. In Suzana bt Md Aris (claiming as administrator of the estate and a dependant of Mohd Anuar bin Sharip, deceased) v. DSP Ishak bin Hussain, [2011] 1 MLJ 107 (HC), 27 (Malay.), the High Court stated: “The UDHR is part and parcel 
Within the Singapore context, certain articles of the UDHR have been invoked for various reasons, as embodying customary human rights law. These include efforts to ground an independent cause of action or to influence and accentuate the interpretation of existing rights. Singapore courts have been careful to examine claims that a UDHR norm has the status of a CIL norm, based on evidence rather than bare assertion.

There are generally four issues that are addressed where CIL norms are invoked to inform constitutional arguments. First, the status of the putative CIL norm must be ascertained and the courts required that this be "clearly and firmly established" before it is adopted. ${ }^{179}$ Second, the manner of reception of a CIL norm into the domestic legal order - it needs to receive judicial recognition or application, without need for legislative incorporation. Third, the content of the CIL norm must be identified, to see if it is breached on the facts. Last, its rank in the domestic hierarchy of legal sources.

A range of UDHR articles have been invoked by counsel to found or buttress claims, with vary degrees of cogency and success. These include matters relating to free speech and assembly (Articles 19 and 20, UDHR); the equal right to property (Articles 7, 17, UDHR), the right to vote (Article

of our jurisprudence as the international norms in the UDHR are binding on all member countries unless they are inconsistent with the member countries' constitutions." In a Hong Kong case relating to the right to asylum, it was stated that the UDHR was "a proclamation of ethical values, rather than legal norms" and so subject to domestic law. See C v. Dir. of Immigration, [2008] H.K.E.C 281 (C.F.I.) (H.K.). The Philippines court noted that its country could "rightfully take credit for the acceptance, as early as 1951, of the binding force of the Universal Declaration of Human Rights even if the rights and freedoms therein declared are considered by other jurisdictions as merely a statement of aspirations and not law until translated into the appropriate covenants. In the following cases decided in 1951, Mejoff v. Director of Prisons, 90 PHIL. ReP. 70 (S.C., July 30, 1949); Borovsky v. Comm'r of Immigration, 90 PHiL. Rep. 107 (S.C., June 30, 1949); Chirskoff v. Comm'r of Immigration, 90 Phil. Rep. (S.C., Oct. 26, 1951); Andreu v. Comm'r of Immigration, 90 PhiL. ReP. 347 (S.C., Oct. 31, 1951), the Supreme Court applied the Universal Declaration of Human Rights. Jose Reyes v. Ramon Bagatsing, G.R. No. L-65366 (S.C., Nov. 9, 1983) (Phil.).

179 Nguyen Tuong Van (2005), 1 SLR (CA), g 88. 
$21)^{180}$ and the prohibition against torture, cruel and inhumane treatment (Article 5).

\section{ARTICLES 19 UDHR - FREEDOM OF SPEECH}

In Yap Keng Ho v. Public Prosecutor, certain demonstrators, including opposition politician Chee Soon Juan, were arrested for holding a demonstration without a police permit after a failed attempt to get one, and were charged under the Miscellaneous Offences (Public Order and Nuisance) (Assemblies and Processions) Rules (Cap 184, R1, 2000 Rev Ed). ${ }^{181}$

It was argued that the police standing policy not to grant permits for outdoor demonstrations was unconstitutional for violating Article 14 of the Constitution (free speech, assembly) and inconsistent with Articles 19 and 20 of the UDHR as customary human rights norms. ${ }^{182}$ It was argued that CIL does not tolerate "massive, arbitrary and disproportionate" bans on free expression. ${ }^{183}$

The High Court stated the proper recourse was an application for judicial review to challenge the police exercise of discretion in refusing a permit, rather than proceeding with the demonstration. ${ }^{184}$ Chee merely asserted that Articles 19 and 20 of the UDHR were binding as CIL norms. ${ }^{185}$ In contrast, the Philippines Supreme Court had an evidential basis for concluding that article 19 of the UDHR was a CIL norm:

Article 19 forms part of the UDHR principles that have been transformed into binding norms. Moreover, many of the rights in the UDHR were included in and elaborated on in the International Covenant on Civil and Political Rights (ICCPR), a treaty ratified by over 150 States, including the Philippines. The recognition of freedom

180 In Vellama d/o Marie Muthu v. Attorney-General, [2012] 2 SLR 1033 (HC) (Sing.), the issue was the scope of the Prime Minister's discretion to call by-elections, which indirectly implicated the right to vote. Article 21 of the UDHR was raised but Pillai J noted that "[ $\mathrm{t}$ ] he UDHR, not having been enacted as Singapore legislation, is not domestic law to which these proceedings relate."

181 Yap Keng Ho v. Pub. Prosecutor, [2011] 3 SLR 32 (HC) (Sing.).

182 Id. 1.

183 Id. 16.

184 Id. $\mathbf{g} 6$.

185 Id. 12. 
of expression is also found in regional human rights instruments, namely, the European Convention on Human Rights (Article 10), the American Convention on Human Rights (Article 10), and the African Charter on Human and Peoples' Rights (Article 9). ${ }^{186}$

\section{ARTICLE 17 UDHR - RIGHT OF PROPERTY}

In Chan Kin Foo v. City Developments Ltd., Chan, a minority shareholder, owned a unit in a block of apartments subject to en bloc collective sale, regulated under sections $84 \mathrm{~A}$ and $84 \mathrm{G}$ of the Land Titles Strata Act (Cap 158, $2009 \mathrm{Rev} \mathrm{Ed}) .{ }^{187} \mathrm{He}$ argued that the sale violated the Article 12 equal guarantee clause as well as Articles 1, 7, and 17 of the UDHR as it discriminated against the right of the minority to own property. ${ }^{188}$

Ang J. noted that the Singapore constitution did not contain a right to property and indeed, this had been omitted deliberately from the Independence Constitution in 1965, owing to land scarcity. ${ }^{189}$ Article 13 of the right to property in the Malaysian Federal Constitution was deliberately left out when Singapore imported most of the Part II fundamental liberties into Part IV (Fundamental Liberties) of the Singapore Constitution. Because of this, it was incumbent upon Chan to provide reasons why Article 17 of the UDHR formed part of local law, and no submissions had been made on this. Ang J. made two observations, obiter. First, that if Article 17 of the UDHR were to have legal effect in Singapore, it must be show to form "part of customary international law." ${ }^{190}$ He stated, "there is no state practice or opinio juris which supports a right to property." ${ }^{191}$ Indeed "widespread state practice" is allowed for "collective sales by majority vote" in countries like Canada, Hong Kong, and America (Hawaii). Further, the existence of

186 Chavez v. Gonzales, G.R. No. 168338, n.27 (S.C., Feb. 15, 2008) (Phil.).

187 Chan Kin Foo v. City Devs. Ltd., [2013] 2 SLR 895 (HC) (Sing.).

188 Id. 9.

189 The 1966 Report of the Constitutional Commission recommended the inclusion of a modified version but this was rejected: Singapore, Report of the Constitutional Commission 1966, (1966) (Chairman: Wee Chong Jin), gg 41-42; Singapore Parliamentary Debates, Official Report (15 March 1967) vol. 25 at 1295-97 (Lee Kuan Yew, Prime Minister).

190 Chan Kin Foo, 2 SLR (HC), 31.

191 Id. 
compulsory land acquisition legislation in Malaysia, India, South Australia, and Pakistan made "wholly untenable"192 the assertion that Article 17 of the UDHR was customary international law. Second, even if the right to property was a CIL norm, these were not self-executing and had first to be incorporated into Singapore law. ${ }^{193}$ No such right had been legislatively incorporated, such that the right to property was "wholly inconsistent" with the Land Titles (Strata) Act. ${ }^{194}$

\section{ARTICLE 10 OF THE UDHR}

A peculiar argument was raised in Re Gavin Millar Q.C. ${ }^{195}$ : a failed application under the Legal Professions Act (Cap 161) to admit a foreign Queen's Counsel to the Singapore bar to hear an allegedly complex liberal case involving senior politicians. ${ }^{196}$

It was argued that since the opposing side had a Senior Counsel, the court ought to give due regard to "the need for a level playing field between the parties to the defamation suits." 197 This was anchored by an appeal to Article 10 of the UDHR, which declares that "Everyone is entitled in full equality to a fair and public hearing by an independent and impartial tribunal, in the determination of his rights and obligations . . ." ${ }^{\prime 98}$ It was contended that inherent in Article 10 was the principle of equality of arms, which would be breached "where there was disparity between the respective levels of legal representation." 199 Two decisions by the European Court of Human Rights were cited to support this propositional argument. ${ }^{200}$ In addition, it was argued that as Singapore was a member of the United

\footnotetext{
$192 I d$.

193 Id. 32.

194 Id. 9 g 28-33. 264 (2008) (Sing.).

197 Re Gavin Millar Q.C., 1 SLR (HC), g 3.

198 Id. 9.

199 Id.

200 Id.
}

195 Re Gavin Millar Q.C., [2008] 1 SLR 297 (HC) (Sing.).

196 See Li-ann Thio, Reading Rights Rightly: The UDHR and Its Creeping Influence on the Development of Singapore Public Law, Singapore Journal of Legal Studies 
Nations, it was bound by the UN Charter to respect UDHR standards. ${ }^{201}$ While the UDHR was aspiration in origin, it is no ordinary General Assembly Resolution. Such resolutions are recommendatory in nature.

In Filartiga $v$. Pena Irala, ${ }^{202}$ which examined whether the prohibition against torture was CIL, it was observed of UN declarations that these were significant "because they specify with great precision the obligations of member nations under the Charter." 203 "Since their adoption, "[m]embers can no longer contend that they do not know what human rights they promised in the Charter to promote." ${ }^{204}$ Indeed, some UN Declarations were "a formal and solemn instrument, suitable for rare occasions when principles of great and lasting importance are being enunciated." ${ }^{205}$ As such, the UDHR “no longer fits into the dichotomy of 'binding treaty' against 'non-binding pronouncement,' but is rather an authoritative statement of the international community." 206 The UDHR created an "expectation of adherence," and "insofar as the expectation is gradually justified by State practice, a declaration may by custom become recognized as laying down rules binding upon the States." 207 The court noted that several commentators considered that the UDHR had totally become a part of binding CIL. ${ }^{208}$

No argument or evidence was put forward to support the view that Article 10 of the UDHR embodied CIL, nor did the High Court decide this question. As the Singapore Constitution does not contain an explicit right to a fair trial, one may speculate as to why Article 10 of the UDHR was invoked

201 Id.

202 Filartiga v. Pena Irala, 630 F.2d 876 (2d Cir. 1980).

203 Id. at 883.

204 Sohn, "A Short History of United Nations Documents on Human Rights," in The United Nations and Human Rights, 18th Report of the Commission (Commission to Study the Organization of Peace ed. 1968) cited in Filartiga v. Pena Irala, 630 F.2d 876 (2d Cir. 1980).

205 Memorandum of Office of Legal Affairs, U.N. Secretariat, 34 U.N. ESCOR, Supp. No. 8 (Vol. 15), U.N. Doc. E/cn.4/1/610 (1962) cited in Filartiga v. Pena Irala, 630 F.2d 876 (2d Cir. 1980).

206 E. Schwelb, Human Rights and the International Community 70 (1964) cited in Filartiga v. Pena Irala, 630 F.2d 876 (2d Cir. 1980).

207 Filartiga v. Pena Irala, 630 F.2d, g 26.

208 Id. 
by counsel within the context of constitutional law argumentation. ${ }^{209}$ It was not invoked to inform the content of an existing constitutional right nor to accentuate the importance of an existing right. Perhaps it was raised to support an argument that there was an implicit right to a fair trial, drawing from conceptions of the rule of $l^{2} w^{210}$ as a constitutional principle. ${ }^{211}$ The European cases would then be used to formulate the content of a fair trial as encompassing the principle of equality of arms. ${ }^{212}$

Alternatively, if Article 10 of the UDHR is customary human rights law, it could have been invoked to establish a free-standing or independent civil right. There is no precedent on this point or whether courts would be receptive to such argument.

\section{ARTICLE 5 OF THE UDHR}

The most illuminating cases in relation to the interpretation of international human rights norms in light of domestic constitutional rules have revolved around Article 5 of the UDHR. This reads: "No one shall be subjected to torture or to cruel, inhuman or degrading treatment or punishment."213

209 Within the context of administrative law, human rights may well be a relevant consideration in the exercise of administrative discretion, as in decisions whether to admit foreign lawyers to the Singapore bar under the Legal Profession Act, 2009, c. 161 (Sing.).

210 Chng Suan Tze v. Minister of Home Affairs, [1988] 2 SLR(R) 525 (CA), 156B.

211 The Law Minister has stated that the right to vote in Singapore was an implied constitutional right, drawn from its system of representative democracy and articles 65 and 66 of the Constitution which provide for General Elections within 3 months after Parliament is dissolved: Kong Chian Lee, Voting in Singapore: A right or a privilege?, Today (Singapore), Feb. 14, 2009, at 6. Implied freedoms derived from a system of representative democracy have been judicially declared in the Australian context. Australian Capital Television Pty. Ltd. v. Commonwealth (1992) 177 CLR 106 (Austl.).

212 Interestingly, Tay J. in discussing the equality of arms principle seemed to focus on the complexity (or otherwise) of the case, rather than the equality of standing between opposing counsel. This is giving substantive content to the principle and implicitly, applying it, either as a relevant consideration in the administrative process, or a right, whether constitutional or common law, which is defeasible rather than absolute. Re Gavin Millar Q.C., 1 SLR (HC), $992-43$.

213 Universal Declaration of Human Rights, supra note 7. 
It has been argued that "death by hanging" and the "mandatory death penalty" violate Article 5 of the UDHR before the Singapore courts. ${ }^{214}$

In Public Prosecutor v. Nguyen Tuong Van, it was argued that "law" in Article 9 of the Singapore Constitution should be read to incorporate Article 5 of the UDHR and further, that "death by hanging" was unconstitutional as it was a cruel and inhumane method of execution. ${ }^{215} \mathrm{Kan} \mathrm{J}$. noted that the UDHR "is not an international treaty" 216 and that there was "no consensus" it codified CIL. ${ }^{217}$ In addition, it did not expressly refer to hanging. ${ }^{218}$ Even assuming that Article 5 of the UDHR codified CIL, the High Court pointed out it was "by no means a settled view"219 that hanging was in fact a cruel, inhumane, or degrading punishment, pointing out the view of the United States Court of Appeals in Campbell v. Wood. ${ }^{220}$ Negative practice in the form of foreign case law was cited to show dissensus that hanging fell clearly into the ambit of Article 5 of the UDHR.

The Court of Appeal went beyond the High Court in finding that article 5 UDHR did embody CIL and that this was "quite widely accepted."221 Notably, the Prosecution did not make any contrary assertions. While accepting that Article 5 of the UDHR embodied CIL, the Court of Appeal found there was "simply not sufficient state practice" to indicate that this prohibition extended to the specific method of death by hanging. ${ }^{222} \mathrm{To}$ demonstrate dissensus, the Court referred to a 2002 UN report from the Commission on Human Rights, which indicated the following in relation to the status of the death penalty worldwide as of 1 December 2002:223

\footnotetext{
214 Nguyen Tuong Van (2004), 2 SLR 328 (HC).

215 Id. g 55.

216 Id. 106.

217 Id.

218 Id.

219 Id. 107.

220 Campbell v. Wood, 18 F.3d 662 (9th Cir. 1994).

221 Nguyen Tuong Van (2005), 1 SLR (CA), 91.

222 Id. 992.

223 Question of the Death Penalty: Report of the Secretary-General submitted pursuant to Commission resolution 2002/77, UN ESCOR, 59th Sess, UN Doc E/ CN.4/2003/106 (2003), cited in Nguyen Tuong Van (2005), 1 SLR (CA), 92.
} 
Number of retentionist countries 71

Number of completely abolitionist countries 77

Number of countries abolitionist for ordinary crimes only 15

Number of countries that can be considered de facto abolitionist 33

Even if death by hanging was cruel and inhuman punishment, the Misuse of Drugs Act which provided for such punishment would prevail over a CIL norm incorporated as part of the common law.

The constitutionality of the mandatory death penalty (MDP) under the Misuse of Drugs Act ${ }^{224}$ was challenged in the case of Yong Vui Kong $v$. Public Prosecutor, ${ }^{225}$ on the basis of two main arguments. First, the MDP was challenged on the basis of Article 9(1) of the Constitution and developments in Privy Council jurisprudence, that the MDP violated Article 9(1) of the Singapore Constitution as being a deprivation of life not in accordance with "law." 226 The MDP constituted an inhumane method of punishment because it treated all guilty persons not as unique individuals with varying degrees of moral blameworthiness, but as a member of a "faceless, undifferentiated mass to be subjected to the blind infliction of the penalty of death." ${ }^{227}$ As such, the MDP legislation is inhuman and contrary to the right to life set out in Article 9(1), as not constituting "law"

224 Misuse of Drugs Act, c.185. This provides for the MDP for crimes of trafficking certain amounts of prohibited drugs.

225 Yong Vui Kong, 3 SLR (CA). For commentaries on this case, see Li-ann Thio, "It is a little known legal fact": Originalism, customary human rights law and constitutional interpretation - Yong Vui Kong v. Public Prosecutor, Singa pore Journal of Legal Studies 558 (2010); Yap Po Jen, Constitutionalising Capital Crimes: Judicial Virtue or 'Originalism' Sin?, Singapore Journal of Legal Studies 281 (2011); Jack Lee, The Mandatory Death Penalty and a Sparsely Worded Constitution, 127 LAW Quarterly Review 192 (2010); Arvind Ganesh, Insulating the Constitution: Yong Vui Kong v. Public Prosecutor [2010] SGCA 20, 10(2) Oxford University Commonwealth Law Journal 273 (2010); Chen Siyuan, The Relationship between International Law and Domestic Law, 23 Singapore Academy of Law JoURnAl 350 (2011).

226 Yong Vui Kong, 3 SLR (CA), g 87-99.

227 Woodson v. North Carolina, 428 U.S. 280, 304 (1976), referenced in Yong Vui Kong, 3 SLR (CA), g 7. 
within its terms. ${ }^{228}$ Privy Council decisions from the Caribbean did not deal with the meaning of the word "law" in analogues of Article 9, but interpreted explicit constitutional clauses that prohibited torture, cruel and inhuman punishment, which the Singapore constitution did not have. ${ }^{229}$ Lord Bingham in Reyes v. The Queen, ${ }^{230}$ a decision from Belize, said the MDP for convicted murderers "long predated any international arrangements for the protection of human rights." ${ }^{231}$ As such, the Singapore Privy Council decision from Singapore, Ong Ah Chuan v. PublicProsecutor ${ }^{232}$ was made "at a time when international jurisprudence on human rights was rudimentary." 233 Various foreign cases from the US, Africa, and India considered that the MDP was inhuman punishment as it precluded judicial sentencing discretion, producing results that were not individualized and disproportionate.

Second, "law" was to be read as incorporating a system of law which did not impose inhumane punishment, drawing from Article 5 of the UDHR as a CIL norm. Article 5 itself did not provide much guidance as to what the content of "inhuman punishment" encompassed.

While affirming the general principle that domestic law should presumptively be interpreted in a manner consistent with Singapore's international human rights obligations, ${ }^{234}$ the Court of Appeal stated there were "inherent limits" to this approach, and identified two major obstacles in the form of the constitutional text and constitutional history.

First, the constitutional text did not contain an express prohibition against inhuman punishment. ${ }^{235}$ This departed from the approach of various Caribbean constitutions that shared the same British legacy of the Westminster parliamentary system, which based their bill of rights on the ECHR. Malaysia and Singapore adopted a distinct constitutional trajectory in this respect. The Court emphasized the "little known legal fact" that

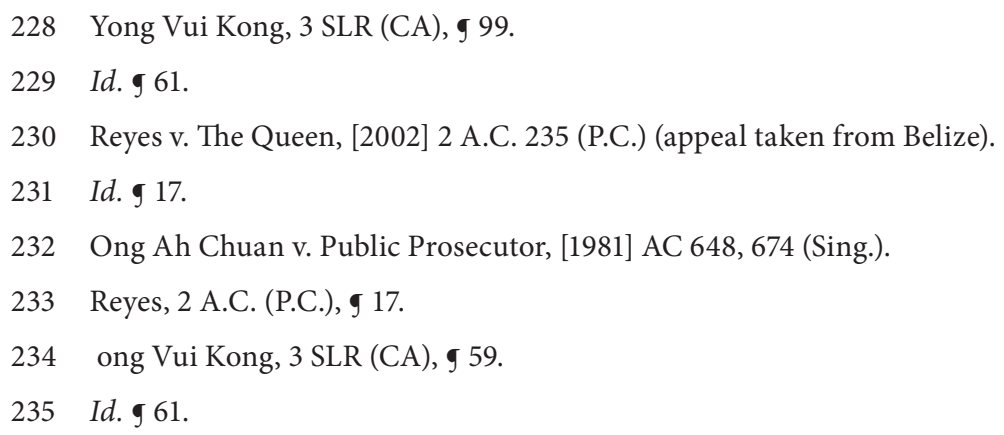


the constitutional drafters must have been aware of the existence of such a inhuman punishment clause given that the ECHR had applied to Malaysia and Singapore in 1953, as well as to other British colonies by virtue of the UK's declaration under Article 63 of the ECHR. ${ }^{236}$

Second, plunging deep into constitutional history, the Court of Appeal showed that the recommendation of the 1966 constitutional commission to include a clause prohibiting torture and inhuman punishment, a new "Article 13," 237 which essentially was modeled after Article 5 of the $\mathrm{UDHR}^{238}$ and Article 3 of the ECHR. ${ }^{239}$ The court found, problematically, ${ }^{240}$ that the government's rejection of Article 13 was "unambiguous," even if

236 Id.

237 The proposed Art. 13 reads: "No person shall be subjected to torture or to inhuman or degrading punishment or other treatment." Clause 2 provided that nothing done "under the authority of any law" in relation to the infliction of punishment or treatment that as lawful prior to the Article came into force shall be held to be inconsistent with the proposed Article. The Court of Appeal was of the opinion that the decision of R v. Hughes, [2002] 2 A.C. 259 (P.C.) (appeal taken from Caribbean) was not applicable as the Art 13(2) "savings" clause, similar to that considered in The Saint Lucia Constitution Order 1978, was not part of the Constitution of the Republic of Singapore (1999 Reprint). Nonetheless, if it had been, they were of the opinion that the 1966 Constitutional Commission (Singapore, Report of the Constitutional Commission, 1966 (1966) (Chairman: Wee Chong Jin)) intended that the proposed Art 13(2) clause was designed to prevent arguments that preexisting lawful punishments would be in violation of Art 13 after the proposed Article 13 took effect. Yong Vui Kong, 3 SLR (CA), g 70.

238 Universal Declaration of Human Rights, supra note 7.

239 European Convention for the Protection of Human Rights and Fundamental Freedoms, opened for signature Nov. 4, 1950, 213 U.N.T.S. 222 (entered into force Sept. 3, 1953).

240 The reasons for not including Article 13 could be given an alternative reading. Perhaps the constitutional framers did not include it because they considered it was covered by article 9 insofar as such prohibition was intrinsic to the idea of "law" demanded by article 9(1). This would be independent of the Court of Appeal's speculation that the constitutional commission recommended Article 13 because they did not believe it was covered within the ambit of article 9(1). See Yong Vui Kong, 3 SLR (CA), gg 71-72. 
the reasons for this were not clear. ${ }^{241}$ The deliberate exclusion of Article 13 was equated with repealing an existing constitutional right. ${ }^{242}$ From this, the Court offered what it considered to be a reasonable assumption; that the Commission recommended a new Article 13 because it was not considered to overlap with the content of Article $9 .{ }^{243}$ Otherwise, its inclusion would be superfluous.

Thus, the court found it illegitimate to read into Article 9(1) the content of what would have been Article 13(1) given that this had been "decisively rejected" by the government in 1969, "especially given the historical context in which the right was rejected." ${ }^{244}$ It was not legitimate to "expand via an interpretative exercise" the scope of Article 9(1) to include a prohibition against inhuman punishment. ${ }^{245}$

The Court took note that the Singapore government had expressed the view that torture was wrong in the local context and that it was criminalized under Penal Code provisions relating to offences affecting the human body. ${ }^{246}$ In "sharp contrast," no government statement has stated that the MDP constitutes inhuman punishment. The Court observed that while the majority of states did not impose the MDP for drug and other serious offences, a "significant number of states" did. ${ }^{247}$ While counsel argued that only 14 countries in the world still retained the MDP for drug offences, the Attorney-General stated there were in fact 31 states who did so. ${ }^{248}$

\footnotetext{
241 Yong Vui Kong, 3 SLR (CA), 72.

242 Id. 74.

243 Id. 972.

244 Id. 92.

245 Id.

246 Singapore Parliamentary Debates, Official Report (29 July 1987) vol. 49, 1491-92 (Prof. S Jayakumar, Minister for Home Affairs); Penal Code, 2008, c. XVI (Sing.), referenced in Yong Vui Kong, 3 SLR (CA), 97.

247 Yong Vui Kong, 3 SLR (CA), g 96.

248 In countries like India where the Supreme Court considered the MDP under section 303 of the Indian Penal Code 1860 (Act No. 45 of 1860) (India), to be unconstitutional, the practice was equivocal as the government subsequently enacted legislation which included the MDP, i.e., the Narcotics Drugs and Psychotropic Substances Act 1985 (Act No. 61 of 1985) (India) and the Scheduled
} 
Thus, applying international legal rules of CIL formation, the Court of Appeal found insufficient state practice, which had to be "extensive and virtually uniform" 249 to indicate that the substantive content of a CIL norm prohibiting inhuman punishment included a specific prohibition of the MDP. ${ }^{250}$

This line of cases shows the reticence of Singapore courts in utilizing international law as a source for expanding or creating new rights; given its judicial modesty and aversion to the prospect of judicial legislation, the Court of Appeal refused to "legislate new rights" under the guise of constitutional interpretation. ${ }^{251} \mathrm{New}$ rights would have to be the produce of parliamentary processes or constitutional amendment. The primacy of democracy and national sovereignty was further underscored in the 2015 Court of Appeal decision of Yong Vui Kong v Public Prosecutor [2015] 2 SLR 1129. Here, the court assumed, for the sake of argument, that the punishment of caning amounted to 'torture'. It noted that there was "strong evidence" that the prohibition against torture was a peremptory international law norm, referencing local parliamentary debates, international tribunals and foreign decisions. ${ }^{252}$ It directly addressed the question of what 'rank' a jus cogens norm would have within the Singapore domestic order.

Citing academic articles and reviewing the summary records of the United Nations Conference on the Law of Treaties, the Court of Appeal rejected the argument that a jus cogens norm, which was a fundamental international norm, applied with constitutional force in the domestic context. It adopted a dualist position, noting that no authority had been provided "for the proposition that a peremptory norm of international law would automatically acquire the status of a constitutional norm when transposed into domestic law." The Court of Appeal underscored that such a proposition would be "untenable" as it would mean that the content of the Singapore constitution "could be dictated by the views of other states,

Castes and the Scheduled Tribes (Prevention of Atrocities) Act 1989 (Act No. 33 of 1989) (India); see Yong Vui Kong, 3 SLR (CA), gg 93-99.

249 North Sea Continental Shelf (Ger. v. Den.) 1969 I.C.J. 3, 74 (Feb. 20), cited in Yong Vui Kong, 3 SLR (CA), 98.

250 Yong Vui Kong, 3 SLR (CA), g 96.

$251 \quad I d .959$.

252 Yong Vui Kong, [2015] 2 SLR 1129 at 1143, [27]. 
regardless of what the people of Singapore, expressing their will through their elected representatives, think." Thus, it held that jus cogens norms could not override domestic statutes "whose meaning and effect is clear." 253 Of course, if Singapore were to violate a jus cogens norm, this did not preclude it being held to account in an international forum, as the court acknowledged. The concept of jus cogens was meant to government international or inter-state relations, rather than to apply with "some special or extraordinary effect at the intra-state level.”254

\section{d. Soft International Law and International Comity}

There have been instances where soft international law norms, in the sense of non- juridically binding international instruments, have been raised by counsel in cases in an attempt to influence the balancing process in adjudicating rights. ${ }^{255}$

For example, the Attorney-General in the contempt of court decision of Attorney-General v. Hertzberg Daniel and others referred to Articles 13 and 14 of the UDHR, ${ }^{256}$ a document adopted by the private Inter-Action Council in 1998, in arguing that different countries guaranteed the right to freedom of expression in different ways such that local conditions were paramount, while foreign case law was not determinative in the local context. ${ }^{257}$ These

\section{$253 I d, 98$.}

$254 I d, 936$.

255 Christine Chinkin, The Challenge of Soft Law: Development and Change in International Law, 38 International \& Comparative Law Quarterly 850 (1989).

256 Article 13: "No politicians, public servants, business leaders, scientists, writers or artists are exempt from general ethical standards, nor are physicians, lawyers and other professionals who have special duties to clients. Professional and other codes of ethics should reflect the priority of general standards such as those of truthfulness and fairness." Article 14: "The freedom of the media to inform the public and to criticize institutions of society and governmental actions, which is essential for a just society, must be used with responsibility and discretion. Freedom of the media carries a special responsibility for accurate and truthful reporting. Sensational reporting that degrades the human person or dignity must at all times be avoided." Universal Declaration of Human Rights, supra note 7.

257 Attorney General v. Hertzberg Daniel, [2009] 1 SLR(R) 1103 (HC), g 11 (Sing.). 
articles related to codes of professional ethics and to the responsibility a free media had for accurate and truthful reporting. Soft international law was invoked as a counterpoint to rights-oriented readings of constitutional rights that valorized individual rights over competing rights, interests, and goods. In other common law jurisdictions, soft law documents may be invoked for the purpose of supporting a rights-expansive or protective reading of constitutions. For example, the Beijing Statement of Principles of the Independence of the Judiciary in the LAWASIA Region, adopted by the Chief Justices of Asia on August 19, 1995 (including the Singapore Chief Justice), was invoked in Vishaka $v$. State of Rajasthan. ${ }^{258}$ This included as an objective of the judiciary the promotion "within the proper limits of the judicial function, the observance and the attainment of human rights." 259 This was invoked to support the extraordinary judicial role in "legislating" anti-sexual harassment guidelines in the absence of legislation. ${ }^{260}$

The same Statement was raised by the defense counsel before the Singapore High Court in Public Prosecutor v. Nguyen Tuong Van, and was treated more dismissively. ${ }^{261}$ The defense sought to add force to its submissions, challenging the constitutionality of the mandatory death penalty in relation to the equal protection clause, and underlining the importance of the judicial role in death penalty cases. ${ }^{262}$ The statement declared the indispensable role of the judiciary in implementing rights under the Universal Declaration of Human Rights (UDHR) and International Covenant on Civil and Political Rights (ICCPR), to which Singapore is not a party. ${ }^{263}$ The judicial function was to promote the "attainment of human rights" and have jurisdiction over all justiciable issues, including sentencing. ${ }^{264}$ Thus, to afford the accused "the equal protection of the law," sentence had to be passed by an independent, impartial tribunal. ${ }^{265}$ This was directed at the mandatory death penalty where courts have no discretion as to sentencing

258 Vishaka, A.I.R. at 3011.

259 Id. g 11.

260 Id.

261 Nguyen Tuong Van (2004), 2 SLR (HC).

262 Id. $72-73$.

263 Id. 100.

264 Id.

265 Id. 
once guilt is found. Kan Ting Chiu J. briefly noted that nothing in the Statement related to death sentences or mandatory death sentences, and counsel failed to explain "how the Statement, which does not have the force of a treaty or a convention, assists the accused's argument that mandatory death sentences are illegal." ${ }^{266}$ The reference to a soft law instrument served only to be some sort of rhetorical flourish rather than a substantive argument.

Attempts to require statute to conform to norms contained in General Assembly resolutions have failed before Indian courts. ${ }^{267}$ In People's Union for Civil Liberties v. Union of India (2005), the argument was raised that the Protection of Human Rights Act (1993) governing the National Human Rights Commission fell short of the Paris Principles of National Human Rights Institutions, endorsed in General Assembly Resolution 48/134 of 1993. ${ }^{268}$ Section 3(2)(d) provides that persons having "knowledge of, or practice experience in, matters relating to human rights" should be appointed commissioners. ${ }^{269}$

The People's Union for Civil Liberties (PUCL) argued that the Paris Principles would be breached if a retired police officer was appointed to be a human rights commissioner, since the police were major human rights violators. ${ }^{270}$ The Court held that the Paris Principles did not exclude police personnel from sitting on national human rights commission (NHRC) and that the General Assembly Resolution could not be exalted to a status of a covenant at international law; even though India had supported the Resolution, this did not cast any binding legal obligation on it. ${ }^{271}$ Soft law norms could not be used to interpret domestic law without regard to the wording of the statutory text, which did not preclude policemen from becoming NHRC members. Soft international law contained in General Assembly resolutions could not be invoked to override express legislation. ${ }^{272}$

Clearly, none of these documents have legally binding force and their utility lies in the realm of their moral force; their power to influence is

\footnotetext{
266 Id. $\mathbf{9} 101$.

267 People’s Union for Civil Liberties v. Union of India, (2005) 2 S.C.C. 436 (India).

268 Id.

269 The Protection of Human Rights (Amendment) Act, 1993, No. 43, Acts of Parliament, 2006 (India).

270 Id.

271 Id.

272 Id.
} 
based on persuasion, not obligation. This is evident in the Malaysian case of Nor Anak Nyawai v. Borneo Pulp Plantation Sdn Bhd, where Judge Ian Chin referred to the standards in the non-binding U.N. Draft Declaration on the Human Rights of Indigenous Peoples, although this decision played "no part in my decision" on the case issues as it did not form "part of the law of our land." ${ }^{273}$ Declaration provisions, such as that relating to the right of indigenous people to protect them from forcible removal from their land and cultural genocide, were cited to serve an educative function. In particular, these standards "provide valuable insight as to how we should approach matters concerning the natives," showing the defendant government authorities their wrongful attitudes towards Sarawak natives and to instruct them concerning the "global attitude towards natives." 274 Thus, soft international human rights law was judicially referenced to serve the purposes of censuring and educating state officials as to global standards, with the hope of shaping future policy and conduct.

International soft law thus provides some sort of moral imperative for courts to acknowledge international standards and values, engaging domestic courts in dialogue with cosmopolitan values.

International comity is not a binding legal obligation but a matter of courtesy and goodwill. It has on occasion influenced judicial review where rights are concerned and is invoked along with some mention of state sovereignty. For example, comity spoke to whether a corruption offence under the Prevention of Corruption Act (PCA) (Cap 241, 1993 Rev Ed) based on a classification between citizens and non-citizens was a reasonable one, so as to meet the requirements of the Article 12 equal protection of the law guarantee in Public Prosecutor v. Taw Cheng Kong. ${ }^{275}$

Section 37(1) of the PCA provides for the application of the PCA to Singapore citizens outside Singapore. ${ }^{276}$ A Singapore citizen in Hong Kong

273 Id. at 298.

274 Id. at 297.

275 Taw Cheng Kong, 2 SLR(R) (CA) 489.

276 "The provisions of this Act have effect, in relation to citizens of Singapore, outside as well as within Singapore; and where an offence under this Act is committed by a citizen of Singapore in any place outside Singapore, he may be dealt with in respect of that offence as if it had been committed in Singapore." Prevention of Corruption Act (Cap 241, 1993 Rev Ed). 
was convicted for a corruption offence and argued that section 37(1) PCA was discriminatory as it would not extend to the same act committed in the same place, presumably with the same impact on Singapore, if the perpetrator was a non-citizen. The classification was therefore under-inclusive and contrary to the Article 12 equal protection constitutional guarantee, bearing in mind the Act's purpose to provide for the more effectual prevention of corruption.

The Court of Appeal noted that a statute "generally operates within the territorial limits of the Parliament that enacted it" and would apply to all persons within that state including foreigners. ${ }^{277}$ It approved an English canon of construction to the effect that if any other construction were possible, an Act would not be construed as tos apply to acts done by foreigners outside the state. ${ }^{278}$ This rule was "based on international law by which one sovereign power is bound to respect the subjects and the rights of all other sovereign powers outside its own territory." 279 This territorial principle in criminal law served various rationales, including avoiding cases when other states may take offense if a country attempts to regulate matters taking place within their territories. ${ }^{280}$

The Court of Appeal noted that non-citizens were left out of the ambit of section 37(1) out of consideration of comity, and consequently, in considering the reasonableness of the classification, the Act's objective "must be balanced against Parliament's intention to observe international comity." 281 Given the broad ambit of section 37(1) which would capture all corrupt acts independent of their harmful consequences in Singapore, the Court of Appeal concluded it was "rational to draw the line at citizenship and leave out non-citizens so as to observe international comity and the sovereignty of other nations." 282 The court agreed with the Attorney-General that section 37(1) PCA was "a piece of highly responsible legislation which took into account international norms and practices." ${ }^{283}$ International law and comity

277 Taw Cheng Kong, 2 SLR(R) (CA), g 66.

278 Id. $9 g$ 66-68.

279 R v. Jameson, [1896] 2 Q.B. 425 at 430 (Eng.).

280 Taw Cheng Kong, 2 SLR(R) (CA), g 69.

281 Id. 70.

282 Id. 75.

283 Id. 83. 
was thus a consideration in the application of the rational classification test to interpret the equal protection clause. ${ }^{284}$ Adopting a dialogical tone, the Court also suggested that Parliament adopt the effects test, which was recognized at international law, ${ }^{285}$ as the basis for its extra-territorial laws. ${ }^{286}$

\section{e. Issues of Recognition and State Immunity before Singapore Courts}

Questions of recognition of putative states/government frequently arise in connection with claims of state immunity before courts, bringing to the fore the role of executive certificates.

These issues arose before the Singapore courts in Civil Aeronautics Administration $v$. Singapore Airlines Ltd. in relation to an air accident when a Singapore Airlines flight took-off from Taipei Airport in Taiwan, which is run by the Civil Aeronautics Administration (CAA), a department under the Ministry of Transport and Communications of the government of Taiwan charged with the administration of civil aviation in the Republic of China. ${ }^{287}$ Injured passengers sued Singapore Airlines, who claimed indemnity from CAA and joined it as third parties to the suit. The CAA then invoked foreign state immunity under section 3(1) read with section 16(1)(c) of Singapore's State Immunity Act (SSIA) (Cap 313, 1979), in an attempt to set aside third party proceedings. ${ }^{288}$

Under this Act, foreign states can claim immunity from the civil jurisdiction of Singapore courts. ${ }^{289}$ This is largely similar to the United Kingdom's State Immunity Act (1978), which endorses a model of restrictive immunity, and was enacted to give effect to the 1972 European Convention

284 Id.

285 E.g., S.S. Lotus (Fr. v. Turk.), judgment, 1927 P.C.I.J. (ser. A) No. 10 (Sept. 7); United States v. Aluminium Co. of America, 148 F.2d 416 (1945).

286 Taw Cheng Kong, 2 SLR(R) (CA), g 88.

287 Civil Aeronautics Admin. v. Singapore Airlines Ltd., [2004] 1 SLR 570 (CA), g 14 (Sing.).

288 Id. 9.

289 State Immunity Act, 2014, c. 313 (Sing.). 
on State Immunity, to which Singapore is not a party. ${ }^{290}$ As the Court of Appeal in Civil Aeronautics Administration v. Singapore Airlines Ltd. has noted, sovereign immunity "is based on mutual respect and international comity ... [requiring] every sovereign state to respect the independence and dignity of every other sovereign state" so as to "decline to exercise by means of its courts, territorial jurisdiction" over the person or public property of the sovereign. ${ }^{291}$ Thus, a sovereign state "could not be sued in the courts of another state unless the former submits to the jurisdiction of the latter." 292

Section 3(1) embodies a general principle of immunity from the jurisdiction of Singapore courts, with stated exceptions. Section 16(1) provides that reference to a state includes, inter alia, reference to "any department of that government." ${ }^{293}$ Section 18 provides that an executive certificate from the Ministry of Foreign Affairs (MFA) "shall be conclusive evidence"

290 Law Minister EW Barker noted that there were certain provisions in the UK Act which were not appropriate to Singapore, "particularly those concerning the European Convention on State Immunity." Thus, while the Singapore Act is based on the UK Act, it "has been modified to suit our needs and circumstances." 'State Immunity Bill', 39 Singapore Parliament Reports 7 Sept 1979 col 408 at 409. None the less, while not being bound by the UK Parliament's intention in adopting the State Immunity Act, references have been made to Hansard to interpret the scope of section 15 of the Singapore State Immunity Act which is in pari material with section 13(2)(b) of the UK Act. It emerged that an original provision to grant immunity for orders for security of costs was deleted from the final bill. Choo Han Teck J held that the Singapore Act does not curtail the court's jurisdiction to order security for costs despite its silence, Such orders were not part of 'enforcement jurisdiction', which is distinct from 'adjudicative jurisdiction' - state consent to submit to the latter does not entail submission to the former. Security for cost orders were "a procedural condition precedent for the continuation of legal proceedings" and did not constitute an affront to the dignity of a foreign sovereign where asked to provide security for the costs of proceedings that sovereign has voluntarily institute in the forum court. See Ministry of Rural Dev., Fishery, Craft Indus. \& Env't of the Union of Comoros v. Chan Leng Leng, [2013] 3 SLR 214 (HC), gg 5, 8 (Sing.).

291 Civil Aeronautics Admin., 1 SLR (CA), 14.

292 Id.

293 State Immunity Act, 2014, c. 313, \$ 16(1) (Sing.). 
on any question as to whether "any country is a State for the purposes of Part II . . .." 294

Counsel for both SIA and CAA wrote to the MFA requesting a positive response to the question of whether the MFA would issue a certificate confirming that Taiwan was a state for the purposes of the SIA. MFA responded to both with a letter stating "we are unable to issue the certificate pursuant to 18 of the State Immunity Act." ${ }^{295}$

\section{PRIMACY OF STATE IMMUNITY ACT OR CUSTOMARY INTERNATIONAL LAW ON SOVEREIGN IMMUNITY - THE TREATMENT OF EXECUTIVE CERTIFICATES}

The High Court in Woo v. Singapore Airlines Limited and Civil Aeronautics Administration (joining), rejected counsel's argument that the court should "follow the principles of international law and draw a distinction between 'de jure and de facto recognition,' given the absence of official recognition of Taiwan as a state by the Singapore government. ${ }^{296}$ Counsel had argued that the court was entitled to determine whether there was a de facto recognition of the Republic of China if the Singapore government's position on this point was unclear. Evidence was set forth before the High Court and on appeal in Civil Aeronautics Administration v. Singapore Airlines Ltd. on the history of Singapore-Taiwan interactions, including the conclusion of a double-taxation treaty, investment and tourism agreements. ${ }^{297}$

However, the High Court, affirmed by the Court of Appeal, held that the refusal of the Ministry of Foreign Affairs (MFA) to issue a certificate stating that the Singapore government recognized Taiwan as a state under the SSIA was conclusive and a clear indication of non-recognition, even if couched in "polite and diplomatic terms." 298 Since the SSIA did not distinguish between de jure or de facto recognition, it had to "be read as inclusive of both." ${ }^{299}$

294 Id. $\$ 18$.

295 Civil Aeronautics Admin., 1 SLR (CA), g 10.

296 Woo v. Singapore Airlines Ltd., [2003] 3 SLR 688 (HC) (Sing.).

297 Civil Aeronautics Admin., 1 SLR (CA), gg 12-28, 34-35.

298 Id. 11.

299 Woo, 3 SLR (HC), 7. 
Ultimately, the CAA was denied immunity from suit under the SSIA, based on the executive's view rather than judicial determination of what international law required. ${ }^{300}$ Several justifications were given for this approach:

\section{i. "One Voice" Doctrine}

The High Court emphasized that the recognition of statehood was something requiring "a common stand to be taken by all the organs of the recognizing state." 301 The SSIA thus requires the application of a "one voice" doctrine as it conferred upon the Executive the power to make a conclusive determination whether to recognize a state or government for the purposes of the Act. This requires judicial deferral to executive determinations as "[r]ecognition by the court follows recognition by the state to which that court belongs." 302

\section{ii. The Determinative Voice of the Executive}

The question of whether Taiwan was entitled to immunity under the SSIA was to be determined by the views of the executive rather than international law. Irrespective of what the court views the status of Taiwan to be under general principles of international law, once the MFA says Taiwan is not a state for SSIA purposes, "the court should fall in line." ${ }^{303}$ This reflects the "pre-eminence given to recognition" 304 under section 18 SSIA.

Citing a string of English cases, the Court of Appeal highlighted Lord Atkin's judgment in Government of the Republic of Spain v. SS Arantzazu Mendi, ${ }^{305}$ which rejected earlier views that the court could examine sec-

300 One might argue that since the SSIA removed immunity from acta jure gestionis (non-sovereign acts of state) and placed the issue from the political to the legal sphere to be determined by the judicial application of international law, pursuant to the doctrine of restrictive immunity, that the SSIA should be construed subject to international law.

301 Woo, 3 SLR (HC), 6.

302 Id. $\mathbf{g} 11$.

303 Civil Aeronautics Admin., 1 SLR (CA), 14.

304 Id. 25.

305 Gov’t of the Republic of Spain v. SS Arantzazu Mendi, [1939] A.C. 256 (H.L.) at 263-64 (Eng.). 
ondary evidence where the Crown declined to answer a question about statehood. ${ }^{306}$ He said "[o]ur state cannot speak with two voices . . . . Our Sovereign has to decide whom he will recognize as a fellow sovereign," and the issue of foreign state immunities must flow from that decision. ${ }^{307}$

\section{iii. Is there No Role for the Court? What about Ambiguity?}

The door was left open as to whether the court could conduct its own independent inquiry ${ }^{308}$ based on other evidence about whether the Singapore government had recognized Taiwan as a state, de facto or de jure, where the MFA's actions were ambiguous. In the instant case, the Court of Appeal asserted that the MFA's reply was clear and had to be viewed in the context of the request, noting it was "not for the judiciary to criticize any obscurity" in the executive's expression. ${ }^{309}$ By refusing to certify that Taiwan was a state for SSIA purposes, the "only logical conclusion" was that Taiwan was not a state within the meaning of the SSIA. ${ }^{310}$

Even if this was ambiguous, the preferred course of action would be to revert to the MFA for "a more specific answer." The Court of Appeal underscored that the issue of recognition of statehood was a matter "wholly within the Executive's domain," 311 being not only a matter of fact but of policy. ${ }^{312}$ There was no room for the courts to "get themselves involved in international relations" which they were ill-equipped to deal with. The sensible option was to seek further clarification rather than second-guess the Executive or determine the answer based on evidence placed before

306 Specifically, Lord Sumner's views in Duff Dev. Co. v. Gov’t of Kelantan, [1924] A.C. 797 (H.L.) (appeal taken from Eng.).

307 SS Arantzazu Mendi, A.C. at 264.

308 The CAA cited In re Al-Fin Corporation's Patent, [1970] Ch. 160 where North Korea was recognized as a "state" for the purposes of section 24 of the UK Patents Act (1949), despite the government not recognizing it. "State" in this context was to be apprehended by the "objective conditions of statehood" as "state" under section 24 did not depend on recognition.

309 GUR Corp. v. Trust Bank of Africa Ltd. \& the Gov’t of Ciskei, [1986] 2 Lloyd's Rep. 451 (A.C.) (Eng.), cited at Civil Aeronautics Admin., 1 SLR (CA), 12.

310 Civil Aeronautics Admin., 1 SLR (CA), 13.

311 Id. 15.

312 Id. 22. 
it. It was only when the Executive refused to respond to a request for an executive certificate, that the courts would take their own decision on the basis of customary international law. ${ }^{313}$

The different approach of the Canadian courts flowed from the fact that their statutory equivalent of section 18 SSIA indicated that a Canadian executive certificate was but one means of determining whether Taiwan was a state for the purposes of the Canadian Act. ${ }^{314}$ In addition, where the executive's reply is vague, the court could consider evidence and come to its own conclusion. ${ }^{315}$

\section{THE SPECIAL QUESTION OF SOVEREIGN IMMUNITY AS DISTINCT FROM STATEHOOD}

The Court of Appeal in Civil Aeronautics Administration v. Singapore Airlines Ltd. stressed that the question of sovereign immunity was "special" and to be treated differently from the different question of whether a state had come into being. A state must first be recognized before it can be accorded state immunity. ${ }^{316}$

Singapore endorses the "declaratory" theory of statehood, that there are four conditions under customary international law for an entity to be a state: defined territory, permanent population, effective government, and the capacity to enter into relations with other states. ${ }^{317}$ Recognition in this conception is not constitutive of statehood but a mere acknowledgement of fact.

However, where sovereign immunity is concerned, "recognition is vital." 318 One cannot respect what one does not recognize. The court evaluated the evidence to see if Singapore had in fact recognized Taiwan

\section{Id. $\operatorname{sg} 27,41$.}

314 See generally Olufemi A. Elias, The International Status of Taiwan in the Courts of Canada and Singapore, 8 Singa pore Year Book of International LaW 93 (2004).

315 Parent v. Singapore Airlines Ltd. \& Civil Aeronautics Admin., [2003] IIJ Can 7285 (Can. Que.).

316 Civil Aeronautics Admin., 1 SLR (CA), g 20.

317 Id. 30.

318 Id. 91. 
as a sovereign state. ${ }^{319}$ The evidence was read in the light of Singapore's one-China policy and the fact that Singapore had treated Taiwan different from other sovereign states. ${ }^{320}$ For example, Taiwan had no diplomatic representation, only a Trade Mission that was not allowed to use the title "republic of China" from 1990 when Singapore established formal relations with the PRC. ${ }^{321}$ The approach was consonant with treating Taiwan as "a political subdivision of another State." 322

While clear that Singapore was in "close co-operation" with Taiwan in various areas like tourism, tax and air services, this did not imply recognition as sovereign state. ${ }^{323}$ Recognition was intentional and could not be easily implied from actions; acts must leave "no doubt" of the intention to recognize, and the acts indicated Singapore had taken care to ensure its actions could not be construed as recognizing Taiwan's status in a manner contrary to it's one-China policy. ${ }^{324}$

\section{CAN YOU SUE SOMETHING WHOSE EXISTENCE YOU DENY?}

The Court of Appeal in Civil Aeronautics Administration v. Singapore Airlines Ltd. rejected the argument that if Taiwan was not a state for the purposes of SSIA, it could not be sued. Taiwan could be a state for other purposes and still have the capacity to sue and be sued, as determined by the law of Taiwan. American case law was cited for the proposition that unrecognized governments were not totally devoid of some legal status. Indeed, the House of Lords articulated a sensible approach insofar as nonrecognition could not be pushed to its "ultimate logical limit," particularly where private acts or daily administrative acts were concerned. ${ }^{325}$ It was thus possible not to grant recognition to an entity for the purposes of state

\section{Id. 32. \\ 320 Id. 34. \\ 321 Id. 99 32-34.}

322 If Taiwan had taken the stand that it should enjoy immunity as part of the People's Republic of China, which Singapore recognizes as a state, this would have been “a serious argument." Id. 8.

323 Id. 35.

324 Id. 36.

325 Carl-Zeiss Stiftung v. Rayner and Keeler Ltd. (No 2), [1967] 1 A.C. 853 (H.L.) (Eng.). 
immunity while permitting it to be sued for its acts, since non-recognition does not deny a foreign government exists, and denies only that it cannot represent the state on the international plane. ${ }^{326}$ As such, Taiwan existed and its government was in effective control over a specific area, and thus the CAA bore responsibility for its role in the tragedy.

\section{LIMITS ON INTERNATIONAL LAW IN SINGAPORE COURTS AND CONCLUDING OBSERVATIONS}

\section{a. Factors Restricting Judicial Review - Non-Justiciability/Act of State}

Certain doctrines and principles, like the act of state doctrine and doctrine of non-justiciability operate to limit judicial review over issues that may engage international law. This implicates constitutional doctrines like the separation of powers.

It has been recognized that there are "clearly provinces of executive decision-making that are, and should be, immune from judicial review." 327 This includes "high policy" matters pertaining to making treaties, recognizing foreign governments, declaring war, the conduct of foreign affairs and international boundary disputes. ${ }^{328}$ The "one voice" policy is adopted to avoid embarrassing the executive in the conduct of foreign relations, locating this in the realm of politics rather than law. Certain issues were more suited to diplomatic settlement as opposed to judicial determination, particularly where highly politicized, complex and contested, placing the court in a "judicial no man's land." 329

The act of state doctrine is a prudential one that limits the forum court from inquiring into the validity and propriety of the sovereign acts of a foreign state committed within its own territory. This immunizes the sovereign acts of a foreign state from judicial review as such acts are considered

326 DW Grieg, The Carl-Zeiss Case and the Position of an Unrecognised Government in English Law, 83 Law Quarterly Review 96 (1967).

327 Lee Hsien Loong v. Review Publ'g Co., [2007] 2 SLR(R) 453 (HC), 95 (Sing.).

328 Id. 96.

329 Kuwait Airways Corp. v. Iraqi Airways Co., [2002] UKHL 19, [113]. 
"automatically non-justiciable by reason of their sovereign nature." 330 This is distinct from the doctrine of sovereign immunity which raises question of jurisdiction, not prudence.

The act of state doctrine only applies if the relevant act is an act of the state, which must be done in the exercise of the supreme sovereign power of a state, as opposed to private acts. ${ }^{331}$ The subject matter of the act must be located within the foreign sovereign's territory. It only applies to acts of foreign legislatures or governments, and not judicial acts, ${ }^{332}$ which were covered by the common law conflicts of law rules on the recognition of foreign judgments. One of its rationales, drawn from international law, is that respect is shown for the independence of other sovereign states when "the courts of one country will not sit in judgment on the acts of the government of another done within its own territory." ${ }^{333}$

As Chao Hick Tin JA noted in Republic of the Philippines v. Maler Foundation, this understanding of act of state emphasizes "the Westphalian notion of sovereignty" under which each state exercised "absolute power and sovereignty within its territorial boundaries." ${ }^{334}$ He noted the American act of state doctrine was "initially conceived from this perspective as a matter of judicial restraint and comity," much like the British approach towards non-justiciability/act of state, which Singapore appears to follow. ${ }^{335}$ However, the American doctrine has since been established on a more constitutionalist basis, resting on the separation of powers. ${ }^{336}$ Under this model, it would be improper for courts to consider certain disputes between foreign sovereigns as judicial intervention might "hinder rather

330 WestLB AG v. Philippine Nat'l Bank, [2012] 4 SLR 894 (HC), g9 38-39 (Sing.).

331 Maldives Airports Co. v. GMR Male Int'l Airport Pte Ltd, [2013] 2 SLR 449 (CA) (Sing.).

332 The Republic of the Philippines v. Maler Found., [2014] 1 SLR 1389 (CA) (Sing.).

333 Chief Justice Fuller, Underhill v. Hernandez, 168 U.S. 250 (1897), discussed in WestLB AG, 4 SLR (HC) at 894.

334 Maler Found., 1 SLR (CA), 42 (referring to Underhill v. Hernandez., 168 U.S. 250 (1897)).

335 Id.

336 Id. 48. 
than further this country's pursuit of goals both for itself and for the community of nations as a whole in the international sphere." 337

These doctrines of judicial restraint may be seen to uphold the international law concept of state sovereignty, in preserving to states the exclusive competence to regulate people and activities within their territorial domains. This truncates the effect of international law as an influence on the development and content of domestic law. However, in English common law practice, exceptions have developed in relation to the act of state doctrine, where English courts will refuse to give effect to the acts and laws of foreign sovereign states where these represent gross human rights violations or violate fundamental principles of international law, such as the prohibition on the use of force, an accepted ius cogens norm. ${ }^{338}$ These sorts of issues have yet to arise in the Singapore context.

\section{b. Concluding Observations}

Gone are the days where the "little island" mentality towards international law translated into judicial dismissiveness towards international law norms and arguments. This is not to say that Singapore courts see themselves as agents of the international community in the enforcement of international norms. Their focal point is more modest and nationalist. There is no fear of judicial over-reaching here in terms of jurisdictional assertions, as one might associate with Belgian courts and legislation, which at its zenith provided for universal jurisdiction for the commission of war crimes. ${ }^{339}$

Nonetheless, Singapore courts are well versed with international law, citing jurists more frequently and carefully distinguishing between lex lata and lex ferenda. International law is no longer an exotic creature but increasingly becoming part of the regular diet of judges. While their first

337 Banco Nacional de Cuba v. Sabbatino, 376 U.S. 398, 423 (1964), quoted in Maler Found., 1 SLR (CA), 40.

338 Oppenheimer v. Cattermole, [1976] A.C. 249 (H.L.) 277-78 (appeal taken from Eng.); Kuwait Airways Corp., [2002] UKHL 19. For a comment, see Li-ann Thio, English Public Policy, the Act of State Doctrine and Flagrant Violations of Fundamental International Law: Kuwait Airways Corp. v. Iraqi Airways Co. (2002), 18 Connecticut Journal of International Law 585 (2003).

339 Michele Hirsch and Nathalie Kumps, The Belgian Law of Universal Jurisdiction Put to the Test, 35 Justice (2003) (Belg.). 
frame of reference is Anglo-American case law, this is not applied wholesale but with discernment, with sensitivity shown to local values. It gives weight to particularism, without descending into the parochialism of the past where Singapore could be characterized as a "little island" whose courts were reactive in rejecting international law, at least when it came to public law.

It is clear that Singapore courts do not accord primacy to international rules within the national legal system, thereby downplaying the transformative role international law could play in the domestic setting. Its dualist sensibility that prevents treaty law from being directly applied in concrete disputes reflects a vindication of state sovereignty in the form of the power to control "whether and how international rights should be enforced in that municipality." 340

The hierarchical superiority of the constitution and statutes to international norms provide the court great latitude not to give effect to international rules. If CIL rules are received by judicial recognition (a form of state consent) as common law rules, they cannot invalidate statutes. This approach consolidates state sovereignty based on the Westphalian model rooted in territorial integrity and the non-interference of states in domestic affairs. In this conception, international law is applied provided it does not conflict with national law; therefore, it cannot pose a serious threat to national values.

340 David J. Bederman, Enforcement and Compliance, in The SPIRIT OF InTERnATIONAL LAW 186, 187-99 (2002). 